\title{
Review \\ Biological, Psychological, and Social Determinants of Depression: A Review of Recent Literature
}

\author{
Olivia Remes ${ }^{1, *}$, João Francisco Mendes ${ }^{2}$ and Peter Templeton ${ }^{3,4}$ (i) \\ 1 Institute for Manufacturing, University of Cambridge, Cambridge CB3 OFS, UK \\ 2 NOVA Medical School, Universidade NOVA de Lisboa, 1099-085 Lisbon, Portugal; jfc49@cam.ac.uk \\ 3 IfM Engage Limited, Institute for Manufacturing, University of Cambridge, Cambridge CB3 OFS, UK; \\ pwt23@cam.ac.uk \\ 4 The William Templeton Foundation for Young People's Mental Health (YPMH), Cambridge CB2 0AH, UK \\ * Correspondence: ror21@cam.ac.uk
}

Citation: Remes, O.; Mendes, J.F.;

Templeton, P. Biological,

Psychological, and Social

Determinants of Depression: A

Review of Recent Literature. Brain Sci.

2021, 11, 1633. https://doi.org/

$10.3390 /$ brainsci11121633

Academic Editor: Agorastos

Agorastos

Received: 27 July 2021

Accepted: 12 November 2021

Published: 10 December 2021

Publisher's Note: MDPI stays neutral with regard to jurisdictional claims in published maps and institutional affiliations.

Copyright: (c) 2021 by the authors. Licensee MDPI, Basel, Switzerland. This article is an open access article distributed under the terms and conditions of the Creative Commons Attribution (CC BY) license (https:/ / creativecommons.org/licenses/by/ $4.0 /)$.

\begin{abstract}
Depression is one of the leading causes of disability, and, if left unmanaged, it can increase the risk for suicide. The evidence base on the determinants of depression is fragmented, which makes the interpretation of the results across studies difficult. The objective of this study is to conduct a thorough synthesis of the literature assessing the biological, psychological, and social determinants of depression in order to piece together the puzzle of the key factors that are related to this condition. Titles and abstracts published between 2017 and 2020 were identified in PubMed, as well as Medline, Scopus, and PsycInfo. Key words relating to biological, social, and psychological determinants as well as depression were applied to the databases, and the screening and data charting of the documents took place. We included 470 documents in this literature review. The findings showed that there are a plethora of risk and protective factors (relating to biological, psychological, and social determinants) that are related to depression; these determinants are interlinked and influence depression outcomes through a web of causation. In this paper, we describe and present the vast, fragmented, and complex literature related to this topic. This review may be used to guide practice, public health efforts, policy, and research related to mental health and, specifically, depression.
\end{abstract}

Keywords: depression; major depressive disorder; risk factor; protective factor; determinant; review

\section{Introduction}

Depression is one of the most common mental health issues, with an estimated prevalence of $5 \%$ among adults [1,2]. Symptoms may include anhedonia, feelings of worthlessness, concentration and sleep difficulties, and suicidal ideation. According to the World Health Organization, depression is a leading cause of disability; research shows that it is a burdensome condition with a negative impact on educational trajectories, work performance, and other areas of life [1,3]. Depression can start early in the lifecourse and, if it remains unmanaged, may increase the risk for substance abuse, chronic conditions, such as cardiovascular disease, and premature mortality [4-8].

Treatment for depression exists, such as pharmacotherapy, cognitive behavioural therapy, and other modalities. A meta-analysis of randomized, placebo-controlled trials of patients shows that $56-60 \%$ of people respond well to active treatment with antidepressants (selective serotonin reuptake inhibitors, tricyclic antidepressants) [9]. However, pharmacotherapy may be associated with problems, such as side-effects, relapse issues, a potential duration of weeks until the medication starts working, and possible limited efficacy in mild cases [10-14]. Psychotherapy is also available, but access barriers can make it difficult for a number of people to get the necessary help.

Studies on depression have increased significantly over the past few decades. However, the literature remains fragmented and the interpretation of heterogeneous findings 
across studies and between fields is difficult. The cross-pollination of ideas between disciplines, such as genetics, neurology, immunology, and psychology, is limited. Reviews on the determinants of depression have been conducted, but they either focus exclusively on a particular set of determinants (ex. genetic risk factors [15]) or population sub-group (ex. children and adolescents [16]) or focus on characteristics measured predominantly at the individual level (ex. focus on social support, history of depression [17]) without taking the wider context (ex. area-level variables) into account. An integrated approach paying attention to key determinants from the biological, psychological, and social spheres, as well as key themes, such as the lifecourse perspective, enables clinicians and public health authorities to develop tailored, person-centred approaches.

The primary aim of this literature review: to address the aforementioned challenges, we have synthesized recent research on the biological, psychological, and social determinants of depression and we have reviewed research from fields including genetics, immunology, neurology, psychology, public health, and epidemiology, among others.

The subsidiary aim: we have paid special attention to important themes, including the lifecourse perspective and interactions between determinants, to guide further efforts by public health and medical professionals.

This literature review can be used as an evidence base by those in public health and the clinical setting and can be used to inform targeted interventions.

\section{Materials and Methods}

We conducted a review of the literature on the biological, psychological, and social determinants of depression in the last 4 years. We decided to focus on these determinants after discussions with academics (from the Manchester Metropolitan University, University of Cardiff, University of Colorado, Boulder, University of Cork, University of Leuven, University of Texas), charity representatives, and people with lived experience at workshops held by the University of Cambridge in 2020. In several aspects, we attempted to conduct this review according to PRISMA guidelines [18].

The inclusion and exclusion criteria are the following:

- Inclusion criteria

- We included documents, such as primary studies, literature reviews, systematic reviews, meta-analyses, reports, and commentaries on the determinants of depression. The determinants refer to variables that appear to be linked to the development of depression, such as physiological factors (e.g., the nervous system, genetics), but also factors that are further away or more distal to the condition. Determinants may be risk or protective factors, and individual- or wider-area-level variables.

- We focused on major depressive disorder, treatment-resistant depression, dysthymia, depressive symptoms, poststroke depression, perinatal depression, as well as depressive-like behaviour (common in animal studies), among others.

- We included papers regardless of the measurement methods of depression.

- We included papers that focused on human and/or rodent research.

- This review focused on articles written in the English language.

- Documents published between 2017-2020 were captured to provide an understanding of the latest research on this topic.

- Exclusion criteria

- Studies that assessed depression as a comorbidity or secondary to another disorder.

- Studies that did not focus on rodent and/or human research.

- Studies that focused on the treatment of depression. We made this decision, because this is an in-depth topic that would warrant a separate stand-alone review.

1. Next, we searched PubMed (2017-2020) using keywords related to depression and determinants. Appendix A contains the search strategy used. We also conducted focused searches in Medline, Scopus, and PsycInfo (2017-2020). 
2. Once the documents were identified through the databases, the inclusion and exclusion criteria were applied to the titles and abstracts. Screening of documents was conducted by O.R., and a subsample was screened by J.M.; any discrepancies were resolved through a communication process.

3. The full texts of documents were retrieved, and the inclusion and exclusion criteria were again applied. A subsample of documents underwent double screening by two authors (O.R., J.M.); again, any discrepancies were resolved through communication.

4. The final list of references that were eligible and met the inclusion criteria was included in a data charting form.

a. A data charting form was created to capture the data elements of interest, including the authors, titles, determinants (biological, psychological, social), and the type of depression assessed by the research (e.g., major depression, depressive symptoms, depressive behaviour).

b. The data charting form was piloted on a subset of documents, and refinements to it were made. The data charting form was created with the data elements described above and tested in 20 studies to determine whether refinements in the wording or language were needed.

c. Data charting was conducted on the documents.

d. Narrative analysis was conducted on the data charting table to identify key themes. When a particular finding was noted more than once, it was logged as a potential theme, with a review of these notes yielding key themes that appeared on multiple occasions. When key themes were identified, one researcher (O.R.) reviewed each document pertaining to that theme and derived concepts (key determinants and related outcomes). This process (a subsample) was verified by a second author (J.M.), and the two authors resolved any discrepancies through communication. Key themes were also checked as to whether they were of major significance to public mental health and at the forefront of public health discourse according to consultations we held with stakeholders from the Manchester Metropolitan University, University of Cardiff, University of Colorado, Boulder, University of Cork, University of Leuven, University of Texas, charity representatives, and people with lived experience at workshops held by the University of Cambridge in 2020.

We condensed the extensive information gleaned through our review into short summaries (with key points boxes for ease of understanding and interpretation of the data).

\section{Results}

Through the searches, 6335 documents, such as primary studies, literature reviews, systematic reviews, meta-analyses, reports, and commentaries, were identified. After applying the inclusion and exclusion criteria, 470 papers were included in this review (Supplementary Table S1). We focused on aspects related to biological, psychological, and social determinants of depression (examples of determinants and related outcomes are provided under each of the following sections.

\subsection{Biological Factors}

The following aspects will be discussed in this section: physical health conditions; then specific biological factors, including genetics; the microbiome; inflammatory factors; stress and hypothalamic-pituitary-adrenal (HPA) axis dysfunction, and the kynurenine pathway. Finally, aspects related to cognition will also be discussed in the context of depression.

\subsubsection{Physical Health Conditions}

Studies on physical health conditions-key points:

- The presence of a physical health condition can increase the risk for depression

- Psychological evaluation in physically sick populations is needed 
- There is large heterogeneity in study design and measurement; this makes the comparison of findings between and across studies difficult

A number of studies examined the links between the outcome of depression and physical health-related factors, such as bladder outlet obstruction, cerebral atrophy, cataract, stroke, epilepsy, body mass index and obesity, diabetes, urinary tract infection, forms of cancer, inflammatory bowel disorder, glaucoma, acne, urea accumulation, cerebral small vessel disease, traumatic brain injury, and disability in multiple sclerosis [19-71]. For example, bladder outlet obstruction has been linked to inflammation and depressive behaviour in rodent research [24]. The presence of head and neck cancer also seemed to be related to an increased risk for depressive disorder [45]. Gestational diabetes mellitus has been linked to depressive symptoms in the postpartum period (but no association has been found with depression in the third pregnancy trimester) [50], and a plethora of other such examples of relationships between depression and physical conditions exist. As such, the assessment of psychopathology and the provision of support are necessary in individuals of ill health [45]. Despite the large evidence base on physical health-related factors, differences in study methodology and design, the lack of standardization when it comes to the measurement of various physical health conditions and depression, and heterogeneity in the study populations makes it difficult to compare studies [50].

The next subsections discuss specific biological factors, including genetics; the microbiome; inflammatory factors; stress and hypothalamic-pituitary-adrenal (HPA) axis dysfunction, and the kynurenine pathway; and aspects related to cognition.

\subsubsection{Genetics}

Studies on genetics-key points:

There were associations between genetic factors and depression; for example:

- The brain-derived neurotrophic factor (BDNF) plays an important role in depression

- Links exist between major histocompatibility complex region genes, as well as various gene polymorphisms and depression

- Single nucleotide polymorphisms (SNPs) of genes involved in the tryptophan catabolites pathway are of interest in relation to depression

A number of genetic-related factors, genomic regions, polymorphisms, and other related aspects have been examined with respect to depression [61,72-140]. The influence of BDNF in relation to depression has been amply studied [117,118,141-143]. Research has shown associations between depression and BDNF (as well as candidate SNPs of the BDNF gene, polymorphisms of the BDNF gene, and the interaction of these polymorphisms with other determinants, such as stress) $[129,144,145]$. Specific findings have been reported: for example, a study reported a link between the BDNF rs6265 allele (A) and major depressive disorder [117].

Other research focused on major histocompatibility complex region genes, endocannabinoid receptor gene polymorphisms, as well as tissue-specific genes and gene co-expression networks and their links to depression $[99,110,112]$. The SNPs of genes involved in the tryptophan catabolites pathway have also been of interest when studying the pathogenesis of depression.

The results from genetics studies are compelling; however, the findings remain mixed. One study indicated no support for depression candidate gene findings [122]. Another study found no association between specific polymorphisms and major depressive disorder [132]. As such, further research using larger samples is needed to corroborate the statistically significant associations reported in the literature.

\subsubsection{Microbiome}

Studies on the microbiome- - key points:

- The gut bacteria and the brain communicate via both direct and indirect pathways called the gut-microbiota-brain axis (the bidirectional communication networks be- 
tween the central nervous system and the gastrointestinal tract; this axis plays an important role in maintaining homeostasis).

- A disordered microbiome can lead to inflammation, which can then lead to depression

- There are possible links between the gut microbiome, host liver metabolism, brain inflammation, and depression

The common themes of this review have focused on the microbiome/microbiota or gut metabolome [146-161], the microbiota-gut-brain axis, and related factors [152,162-167]. When there is an imbalance in the intestinal bacteria, this can interfere with emotional regulation and contribute to harmful inflammatory processes and mood disorders [148, $151,153,155,157]$. Rodent research has shown that there may be a bidirectional association between the gut microbiota and depression: a disordered gut microbiota can play a role in the onset of this mental health problem, but, at the same time, the existence of stress and depression may also lead to a lower level of richness and diversity in the microbiome [158].

Research has also attempted to disentangle the links between the gut microbiome, host liver metabolism, brain inflammation, and depression, as well as the role of the ratio of lactobacillus to clostridium [152]. The literature has also examined the links between medication, such as antibiotics, and mood and behaviour, with the findings showing that antibiotics may be related to depression $[159,168]$. The links between the microbiome and depression are complex, and further studies are needed to determine the underpinning causal mechanisms.

\subsubsection{Inflammation}

Studies on inflammation-key points:

- Pro-inflammatory cytokines are linked to depression

- Pro-inflammatory cytokines, such as the tumour necrosis factor (TNF)-alpha, may play an important role

- Different methods of measurement are used, making the comparison of findings across studies difficult

Inflammation has been a theme in this literature review $[60,161,164,169-184]$. The findings show that raised levels of inflammation (because of factors such as pro-inflammatory cytokines) have been associated with depression $[60,161,174,175,178]$. For example, proinflammatory cytokines, such as tumour necrosis factor (TNF)-alpha, have been linked to depression [185]. Various determinants, such as early life stress, have also been linked to systemic inflammation, and this can increase the risk for depression [186].

Nevertheless, not everyone with elevated inflammation develops depression; therefore, this is just one route out of many linked to pathogenesis. Despite the compelling evidence reported with respect to inflammation, it is difficult to compare the findings across studies because of different methods used to assess depression and its risk factors.

\subsubsection{Stress and HPA Axis Dysfunction}

Studies on stress and HPA axis dysfunction-key points:

- Stress is linked to the release of proinflammatory factors

- The dysregulation of the HPA axis is linked to depression

- Determinants are interlinked in a complex web of causation

Stress was studied in various forms in rodent populations and humans [144,145,155, $174,176,180,185-211]$.

Although this section has some overlap with others (as is to be expected because all of these determinants and body systems are interlinked), a number of studies have focused on the impact of stress on mental health. Stress has been mentioned in the literature as a risk factor of poor mental health and has emerged as an important determinant of depression. The effects of this variable are wide-ranging, and a short discussion is warranted.

Stress has been linked to the release of inflammatory factors, as well as the development of depression [204]. When the stress is high or lasts for a long period of time, this 
may negatively impact the brain. Chronic stress can impact the dendrites and synapses of various neurons, and may be implicated in the pathway leading to major depressive disorder [114]. As a review by Uchida et al. indicates, stress may be associated with the "dysregulation of neuronal and synaptic plasticity" [114]. Even in rodent studies, stress has a negative impact: chronic and unpredictable stress (and other forms of tension or stress) have been linked to unusual behaviour and depression symptoms [114].

The depression process and related brain changes, however, have also been linked to the hyperactivity or dysregulation of the HPA axis [127,130,131,182,212]. One review indicates that a potential underpinning mechanism of depression relates to "HPA axis abnormalities involved in chronic stress" [213]. There is a complex relationship between the HPA axis, glucocorticoid receptors, epigenetic mechanisms, and psychiatric sequelae [130,212].

In terms of the relationship between the HPA axis and stress and their influence on depression, the diathesis-stress model offers an explanation: it could be that early stress plays a role in the hyperactivation of the HPA axis, thus creating a predisposition "towards a maladaptive reaction to stress". When this predisposition then meets an acute stressor, depression may ensue; thus, in line with the diathesis-stress model, a pre-existing vulnerability and stressor can create fertile ground for a mood disorder [213]. An integrated review by Dean and Keshavan [213] suggests that HPA axis hyperactivity is, in turn, related to other determinants, such as early deprivation and insecure early attachment; this again shows the complex web of causation between the different determinants.

\subsubsection{Kynurenine Pathway}

Studies on the kynurenine pathway-key points:

- The kynurenine pathway is linked to depression

- Indolamine 2,3-dioxegenase (IDO) polymorphisms are linked to postpartum depression

The kynurenine pathway was another theme that emerged in this review [120,178, 181,184,214-221]. The kynurenine pathway has been implicated not only in general depressed mood (inflammation-induced depression) [184,214,219] but also postpartum depression [120]. When the kynurenine metabolism pathway is activated, this results in metabolites, which are neurotoxic.

A review by Jeon et al. notes a link between the impairment of the kynurenine pathway and inflammation-induced depression (triggered by treatment for various physical diseases, such as malignancy). The authors note that this could represent an important opportunity for immunopharmacology [214]. Another review by Danzer et al. suggests links between the inflammation-induced activation of indolamine 2,3-dioxegenase (the enzyme that converts tryptophan to kynurenine), the kynurenine metabolism pathway, and depression, and also remarks about the "opportunities for treatment of inflammationinduced depression" [184].

\subsubsection{Cognition}

Studies on cognition and the brain-key points:

- Cognitive decline and cognitive deficits are linked to increased depression risk

- Cognitive reserve is important in the disability/depression relationship

- Family history of cognitive impairment is linked to depression

A number of studies have focused on the theme of cognition and the brain. The results show that factors, such as low cognitive ability/function, cognitive vulnerability, cognitive impairment or deficits, subjective cognitive decline, regression of dendritic branching and hippocampal atrophy/death of hippocampal cells, impaired neuroplasticity, and neurogenesis-related aspects, have been linked to depression [131,212,222-239]. The cognitive reserve appears to act as a moderator and can magnify the impact of certain determinants on poor mental health. For example, in a study in which participants with multiple sclerosis also had low cognitive reserve, disability was shown to increase the risk for depression [63]. Cognitive deficits can be both causal and resultant in depression. 
A study on individuals attending outpatient stroke clinics showed that lower scores in cognition were related to depression; thus, cognitive impairment appears to be associated with depressive symptomatology [226]. Further, Halahakoon et al. [222] note a metaanalysis [240] that shows that a family history of cognitive impairment (in first degree relatives) is also linked to depression.

In addition to cognitive deficits, low-level cognitive ability [231] and cognitive vulnerability [232] have also been linked to depression. While cognitive impairment may be implicated in the pathogenesis of depressive symptoms [222], negative information processing biases are also important; according to the 'cognitive neuropsychological' model of depression, negative affective biases play a central part in the development of depression [222,241]. Nevertheless, the evidence on this topic is mixed and further work is needed to determine the underpinning mechanisms between these states.

\subsection{Psychological Factors}

Studies on psychological factors-key points:

- There are many affective risk factors linked to depression

- Determinants of depression include negative self-concept, sensitivity to rejection, neuroticism, rumination, negative emotionality, and others

A number of studies have been undertaken on the psychological factors linked to depression (including mastery, self-esteem, optimism, negative self-image, current or past mental health conditions, and various other aspects, including neuroticism, brooding, conflict, negative thinking, insight, cognitive fusion, emotional clarity, rumination, dysfunctional attitudes, interpretation bias, and attachment style) $[66,128,140,205,210$, $228,235,242-290]$. Determinants related to this condition include low self-esteem and shame, among other factors $[269,270,275,278]$. Several emotional states and traits, such as neuroticism $[235,260,271,278]$, negative self-concept (with self-perceptions of worthlessness and uselessness), and negative interpretation or attention biases have been linked to depression $[261,271,282,283,286]$. Moreover, low emotional clarity has been associated with depression [267]. When it comes to the severity of the disorder, it appears that meta-emotions ("emotions that occur in response to other emotions (e.g., guilt about anger)" [268]) have a role to play in depression [268].

A determinant that has received much attention in mental health research concerns rumination. Rumination has been presented as a mediator but also as a risk factor for depression $[57,210,259]$. When studied as a risk factor, it appears that the relationship of rumination with depression is mediated by variables that include limited problem-solving ability and insufficient social support [259]. However, rumination also appears to act as a mediator: for example, this variable (particularly brooding rumination) lies on the causal pathway between poor attention control and depression [265]. This shows that determinants may present in several forms: as moderators or mediators, risk factors or outcomes, and this is why disentangling the relationships between the various factors linked to depression is a complex task.

The psychological determinants are commonly researched variables in the mental health literature. A wide range of factors have been linked to depression, such as the aforementioned determinants, but also: (low) optimism levels, maladaptive coping (such as avoidance), body image issues, and maladaptive perfectionism, among others [269,270, $272,273,275,276,279,285,286]$. Various mechanisms have been proposed to explain the way these determinants increase the risk for depression. One of the underpinning mechanisms linking the determinants and depression concerns coping. For example, positive fantasy engagement, cognitive biases, or personality dispositions may lead to emotion-focused coping, such as brooding, and subsequently increase the risk for depression [272,284,287]. Knowing the causal mechanisms linking the determinants to outcomes provides insight for the development of targeted interventions. 


\subsection{Social Determinants}

Studies on social determinants-key points:

- Social determinants are the conditions in the environments where people are born, live, learn, work, play, etc.; these influence (mental) health [291]

- There are many social determinants linked to depression, such as sociodemographics, social support, adverse childhood experiences

- Determinants can be at the individual, social network, community, and societal levels

Studies also focused on the social determinants of (mental) health; these are the conditions in which people are born, live, learn, work, play, and age, and have a significant influence on wellbeing [291]. Factors such as age, social or socioeconomic status, social support, financial strain and deprivation, food insecurity, education, employment status, living arrangements, marital status, race, childhood conflict and bullying, violent crime exposure, abuse, discrimination, (self)-stigma, ethnicity and migrant status, working conditions, adverse or significant life events, illiteracy or health literacy, environmental events, job strain, and the built environment have been linked to depression, among others [52,133,235,236,239,252,269,280,292-371]. Social support and cohesion, as well as structural social capital, have also been identified as determinants [140,228,239,269,293,372-379]. In a study, part of the findings showed that low levels of education have been shown to be linked to post-stroke depression (but not severe or clinical depression outcomes) [299]. A study within a systematic review indicated that having only primary education was associated with a higher risk of depression compared to having secondary or higher education (although another study contrasted this finding) [296]. Various studies on socioeconomic status-related factors have been undertaken [239,297]; the research has shown that a low level of education is linked to depression [297]. Low income is also related to depressive disorders [312]. By contrast, high levels of education and income are protective [335].

A group of determinants touched upon by several studies included adverse childhood or early life experiences: ex. conflict with parents, early exposure to traumatic life events, bullying and childhood trauma were found to increase the risk of depression (ex. through pathways, such as inflammation, interaction effects, or cognitive biases) $[161,182,258,358$, 362,380].

Gender-related factors were also found to play an important role with respect to mental health [235,381-385]. Gender inequalities can start early on in the lifecourse, and women were found to be twice as likely to have depression as men. Gender-related factors were linked to cognitive biases, resilience and vulnerabilities [362,384].

Determinants can impact mental health outcomes through underpinning mechanisms. For example, harmful determinants can influence the uptake of risk behaviours. Risk behaviours, such as sedentary behaviour, substance abuse and smoking/nicotine exposure, have been linked to depression [226,335,355,385-401]. Harmful determinants can also have an impact on diet. Indeed, dietary aspects and diet components (ex. vitamin D, folate, selenium intake, iron, vitamin B12, vitamin K, fiber intake, zinc) as well as dietrelated inflammatory potential have been linked to depression outcomes $[161,208,236,312$, 396,402-428]. A poor diet has been linked to depression through mechanisms such as inflammation [428].

Again, it is difficult to constrict diet to the 'social determinants of health' category as it also relates to inflammation (biological determinants) and could even stand alone as its own category. Nevertheless, all of these factors are interlinked and influence one another in a complex web of causation, as mentioned elsewhere in the paper.

Supplementary Figure S1 contains a representation of key determinants acting at various levels: the individual, social network, community, and societal levels. The determinants have an influence on risk behaviours, and this, in turn, can affect the mood (i.e., depression), body processes (ex. can increase inflammation), and may negatively influence brain structure and function. 


\subsection{Others}

Studies on 'other' determinants—-key points:

- A number of factors are related to depression

- These may not be as easily categorized as the other determinants in this paper

A number of factors arose in this review that were related to depression; it was difficult to place these under a specific heading above, so this 'other' category was created. A number of these could be sorted under the 'social determinants of depression' category. For example, being exposed to deprivation, hardship, or adversity may increase the risk for air pollution exposure and nighttime shift work, among others, and the latter determinants have been found to increase the risk for depression. Air pollution could also be regarded as an ecologic-level (environmental) determinant of mental health.

Nevertheless, we have decided to leave these factors in a separate category (because their categorization may not be as immediately clear-cut as others), and these factors include: low-level light [429], weight cycling [430], water contaminants [431], trade [432], air pollution [433,434], program-level variables (ex. feedback and learning experience) [435], TV viewing [436], falls [437], various other biological factors [116,136,141,151,164,182, 363,364,438-469], mobile phone use [470], ultrasound chronic exposure [471], nighttime shift work [472], work accidents [473], therapy enrollment [226], and exposure to light at night [474].

\section{Cross-Cutting Themes}

\subsection{Lifecourse Perspective}

Studies on the lifecourse perspective-key points:

- Early life has an importance on mental health

- Stress has been linked to depression

- In old age, the decline in social capital is important

Trajectories and life events are important when it comes to the lifecourse perspective. Research has touched on the influence of prenatal or early life stress on an individual's mental health trajectory $[164,199,475]$. Severe stress that occurs in the form of early-life trauma has also been associated with depressive symptoms [362,380]. It may be that some individuals exposed to trauma develop thoughts of personal failure, which then serve as a catalyst of depression [380].

At the other end of the life trajectory-old age-specific determinants have been linked to an increased risk for depression. Older people are at a heightened risk of losing their social networks, and structural social capital has been identified as important in relation to depression in old age [293].

\subsection{Gene-Environment Interactions}

Studies on gene-environment interactions-key points:

- The environment and genetics interact to increase the risk of depression

- The etiology of depression is multifactorial

- Adolescence is a time of vulnerability

A number of studies have touched on gene-environment interactions $[72,77,82,119$, 381,476-481]. The interactions between genetic factors and determinants, such as negative life events (ex. relationship and social difficulties, serious illness, unemployment and financial crises) and stressors (ex. death of spouse, minor violations of law, neighbourhood socioeconomic status) have been studied in relation to depression [82,135,298,449,481]. A study reported an interaction of significant life events with functional variation in the serotonin-transporter-linked polymorphic region (5-HTTLPR) allele type (in the context of multiple sclerosis) and linked this to depression [361], while another reported an interaction between stress and 5-HTTLPR in relation to depression [480]. Other research reported that the genetic variation of HPA-axis genes has moderating effects on the relationship between 
stressors and depression [198]. Another study showed that early-life stress interacts with gene variants to increase the risk for depression [77].

Adolescence is a time of vulnerability $[111,480]$. Perceived parental support has been found to interact with genes (GABRR1, GABRR2), and this appears to be associated with depressive symptoms in adolescence [480]. It is important to pay special attention to critical periods in the lifecourse so that adequate support is provided to those who are most vulnerable.

The etiology of depression is multifactorial, and it is worthwhile to examine the interaction between multiple factors, such as epigenetic, genetic, and environmental factors, in order to truly understand this mental health condition. Finally, taking into account critical periods of life when assessing gene-environment interactions is important for developing targeted interventions.

\section{Discussion}

Depression is one of the most common mental health conditions, and, if left untreated, it can increase the risk for substance abuse, anxiety disorders, and suicide. In the past 20 years, a large number of studies on the risk and protective factors of depression have been undertaken in various fields, such as genetics, neurology, immunology, and epidemiology. However, there are limitations associated with the extant evidence base. The previous syntheses on depression are limited in scope and focus exclusively on social or biological factors, population sub-groups, or examine depression as a comorbidity (rather than an independent disorder). The research on the determinants and causal pathways of depression is fragmentated and heterogeneous, and this has not helped to stimulate progress when it comes to the prevention and intervention of this condition-specifically unravelling the complexity of the determinants related to this condition and thus refining the prevention and intervention methods.

The scope of this paper was to bring together the heterogeneous, vast, and fragmented literature on depression and paint a picture of the key factors that contribute to this condition. The findings from this review show that there are important themes when it comes to the determinants of depression, such as: the microbiome, dysregulation of the HPA axis, inflammatory reactions, the kynurenine pathway, as well as psychological and social factors. It may be that physical factors are proximal determinants of depression, which, in turn, are acted on by more distal social factors, such as deprivation, environmental events, and social capital.

The Marmot Report [291], the World Health Organization [482], and Compton et al. [483] highlight that the most disadvantaged segments of society are suffering (the socioeconomic context is important), and this inequality in resources has translated to inequality in mental health outcomes [483]. To tackle the issue of egalitarianism and restore equality in the health between the groups, the social determinants need to be addressed [483]. A wide range of determinants of mental health have been identified in the literature: age, gender, ethnicity, family upbringing and early attachment patterns, social support, access to food, water and proper nutrition, and community factors. People spiral downwards because of individual- and societal-level circumstances; therefore, these circumstances along with the interactions between the determinants need to be considered.

Another important theme in the mental health literature is the lifecourse perspective. This shows that the timing of events has significance when it comes to mental health. Early life is a critical period during the lifespan at which cognitive processes develop. Exposure to harmful determinants, such as stress, during this period can place an individual on a trajectory of depression in adulthood or later life. When an individual is exposed to harmful determinants during critical periods and is also genetically predisposed to depression, the risk for the disorder can be compounded. This is why aspects such as the lifecourse perspective and gene-environment interactions need to be taken into account. Insight into this can also help to refine targeted interventions. 
A number of interventions for depression have been developed or recommended, addressing, for example, the physical factors described here and lifestyle modifications. Interventions targeting various factors, such as education and socioeconomic status, are needed to help prevent and reduce the burden of depression. Further research on the efficacy of various interventions is needed. Additional studies are also needed on each of the themes described in this paper, for example: the biological factors related to postpartum depression [134], and further work is needed on depression outcomes, such as chronic, recurrent depression [452]. Previous literature has shown that chronic stress (associated with depression) is also linked to glucocorticoid receptor resistance, as well as problems with the regulation of the inflammatory response [484]. Further work is needed on this and the underpinning mechanisms between the determinants and outcomes. This review highlighted the myriad ways of measuring depression and its determinants [66,85,281,298,451,485]. Thus, the standardization of the measurements of the outcomes (ex. a gold standard for measuring depression) and determinants is essential; this can facilitate comparisons of findings across studies.

\subsection{Strengths}

This paper has important strengths. It brings together the wide literature on depression and helps to bridge disciplines in relation to one of the most common mental health problems. We identified, selected, and extracted data from studies, and provided concise summaries.

\subsection{Limitations}

The limitations of the review include missing potentially important studies; however, this is a weakness that cannot be avoided by literature reviews. Nevertheless, the aim of the review was not to identify each study that has been conducted on the risk and protective factors of depression (which a single review is unable to capture) but rather to gain insight into the breadth of literature on this topic, highlight key biological, psychological, and social determinants, and shed light on important themes, such as the lifecourse perspective and gene-environment interactions.

\section{Conclusions}

We have reviewed the determinants of depression and recognize that there are a multitude of risk and protective factors at the individual and wider ecologic levels. These determinants are interlinked and influence one another. We have attempted to describe the wide literature on this topic, and we have brought to light major factors that are of public mental health significance. This review may be used as an evidence base by those in public health, clinical practice, and research.

This paper discusses key areas in depression research; however, an exhaustive discussion of all the risk factors and determinants linked to depression and their mechanisms is not possible in one journal article-which, by its very nature, a single paper cannot do. We have brought to light overarching factors linked to depression and a workable conceptual framework that may guide clinical and public health practice; however, we encourage other researchers to continue to expand on this timely and relevant work-particularly as depression is a top priority on the policy agenda now.

Supplementary Materials: The following are available online at https:/ /www.mdpi.com/article/ 10.3390/brainsci11121633/s1, Figure S1: Conceptual framework: Determinants of depression, Table S1: Data charting-A selection of determinants from the literature.

Author Contributions: O.R. was responsible for the design of the study and methodology undertaken. Despite P.T.'s involvement in YPMH, he had no role in the design of the study; P.T. was responsible for the conceptualization of the study. Validation was conducted by O.R. and J.F.M. Formal analysis (data charting) was undertaken by O.R. O.R. and P.T. were involved in the investigation, resource acquisition, and data presentation. The original draft preparation was undertaken 
by O.R. The writing was conducted by O.R., with review and editing by P.T. and J.F.M. Funding acquisition was undertaken by O.R. and P.T. All authors have read and agreed to the published version of the manuscript.

Funding: This research was funded by The William Templeton Foundation for Young People's Mental Health, Cambridge Philosophical Society, and the Aviva Foundation.

Acknowledgments: Thank you to Isla Kuhn for the help with the Medline, Scopus, and PsycInfo database searches.

Conflicts of Interest: The funders had no role in the design of the study; in the collection, analyses, or interpretation of data; in the writing of the manuscript, or in the decision to publish the results.

\section{Appendix A}

\section{Appendix A.1. Search Strategy}

PubMed

Search: $\left(\left(\left(()\left(\left(\left(()\left(\left(\left(\left({ }^{\prime \prime G e n e-E n v i r o n m e n t ~ I n t e r a c t i o n ”[M a j r]) ~ O R ~(“ G e n e t i c s ”[M e s h])) ~}\right.\right.\right.\right.\right.\right.\right.\right.\right.\right.$ OR ("Genome-Wide Association Study"[Majr])) OR ("Microbiota"[Mesh] OR "Gastrointestinal Microbiome"[Mesh])) OR ("Neurogenic Inflammation"[Mesh])) OR ("genetic determinant")) OR ("gut-brain-axis")) OR ("Kynurenine"[Majr])) OR ("Cognition"[Mesh])) OR ("Neuronal Plasticity"[Majr])) OR ("Neurogenesis"[Mesh])) OR ("Genes"[Mesh])) OR ("Neurology"[Majr])) OR ("Social Determinants of Health"[Majr])) OR ("Glucocorticoids"[Mesh])) OR ("Tryptophan"[Mesh])) AND ("Depression"[Mesh] OR "Depressive Disorder"[Mesh]) Filters: from 2017-2020.

Ovid MEDLINE(R) and Epub Ahead of Print, In-Process, In-Data-Review \& Other Non-Indexed Citations, Daily and Versions(R)

1. $\exp { }^{*}$ Depression/

2. $\exp { }^{*}$ Depressive Disorder/

3. 1 or 2

4. exp *"Social Determinants of Health" /

5. exp *Tryptophan/

6. $\exp { }^{*}$ Glucocorticoids /

7. $\quad \exp { }^{*}$ Neurology/

8. $\exp { }^{*}$ Genes /

9. $\exp { }^{*}$ Neurogenesis /

10. $\exp { }^{*}$ Neuronal Plasticity /

11. $\exp { }^{*}$ Kynurenine/

12. $\exp { }^{*}$ Genetics /

13. $\exp { }^{*}$ Neurogenic Inflammation/

14. $\exp { }^{*}$ Gastrointestinal Microbiome/

15. $\exp { }^{*}$ Genome-Wide Association Study /

16. $\exp ^{*}$ Gene-Environment Interaction/

17. $\exp { }^{*}$ Depression/et [Etiology]

18. $\exp { }^{*}$ Depressive Disorder/et

19. 17 or 18

20. or $/ 4-16$

21. 3 and 20

22. 19 or 21

23. limit 22 to $\mathrm{yr}=$ "2017-Current"

24. "cause* of depression".mp.

25. "cause ${ }^{*}$ of depression".ti.

26. 23 or 25

27. (cause adj3 (depression or depressive)).ti.

28. (caus* adj3 (depression or depressive)).ti.

29. 23 or 28 
Appendix A.2. PsycInfo

\begin{tabular}{|c|c|c|c|}
\hline$\#$ & Query & Limiters/Expanders & Last Run Via \\
\hline S10 & $\begin{array}{c}\text { (S3 OR S4 OR S5 OR S6 OR S7) AND (S1 OR } \\
\text { S8) }\end{array}$ & $\begin{array}{l}\text { Limiters-Publication Year: } \\
\text { 2017-2021 } \\
\text { Expanders-Apply equivalent } \\
\text { subjects } \\
\text { Search modes-Boolean/Phrase }\end{array}$ & $\begin{array}{l}\text { Interface-EBSCOhost Research } \\
\text { Databases } \\
\text { Search Screen-Advanced Search } \\
\text { Database-APA PsycInfo }\end{array}$ \\
\hline S9 & $\begin{array}{c}\text { (S3 OR S4 OR S5 OR S6 OR S7) AND (S1 OR } \\
\text { S8) }\end{array}$ & $\begin{array}{l}\text { Expanders-Apply equivalent } \\
\text { subjects } \\
\text { Search modes-Boolean/Phrase }\end{array}$ & $\begin{array}{l}\text { Interface-EBSCOhost Research } \\
\text { Databases } \\
\text { Search Screen-Advanced Search } \\
\text { Database-APA PsycInfo }\end{array}$ \\
\hline S8 & S3 OR S4 OR S5 OR S6 OR S7 & $\begin{array}{l}\text { Expanders-Apply equivalent } \\
\text { subjects } \\
\text { Search modes-Boolean/Phrase }\end{array}$ & $\begin{array}{l}\text { Interface-EBSCOhost Research } \\
\text { Databases } \\
\text { Search Screen-Advanced Search } \\
\text { Database-APA PsycInfo }\end{array}$ \\
\hline S7 & TI (Social Determinants of Health) & $\begin{array}{l}\text { Expanders-Apply equivalent } \\
\text { subjects } \\
\text { Search modes-Boolean/Phrase }\end{array}$ & $\begin{array}{l}\text { Interface-EBSCOhost Research } \\
\text { Databases } \\
\text { Search Screen-Advanced Search } \\
\text { Database-APA PsycInfo }\end{array}$ \\
\hline S6 & TI (Neurogenic Inflammation) & $\begin{array}{l}\text { Expanders-Apply equivalent } \\
\text { subjects } \\
\text { Search modes-Boolean/Phrase }\end{array}$ & $\begin{array}{l}\text { Interface-EBSCOhost Research } \\
\text { Databases } \\
\text { Search Screen-Advanced Search } \\
\text { Database-APA PsycInfo }\end{array}$ \\
\hline S5 & TI (Genome-Wide Association Study) & $\begin{array}{l}\text { Expanders-Apply equivalent } \\
\text { subjects } \\
\text { Search modes-Boolean/Phrase }\end{array}$ & $\begin{array}{l}\text { Interface-EBSCOhost Research } \\
\text { Databases } \\
\text { Search Screen-Advanced Search } \\
\text { Database-APA PsycInfo }\end{array}$ \\
\hline S4 & TI (Gene-Environment Interaction) & $\begin{array}{l}\text { Expanders-Apply equivalent } \\
\text { subjects } \\
\text { Search modes-Boolean/Phrase }\end{array}$ & $\begin{array}{l}\text { Interface-EBSCOhost Research } \\
\text { Databases } \\
\text { Search Screen-Advanced Search } \\
\text { Database-APA PsycInfo }\end{array}$ \\
\hline & $\begin{array}{c}\text { (((((MM “Etiology” OR MM “Causality”) OR } \\
\text { (MM “Tryptophan” OR MM } \\
\text { “Hydroxytryptophan (5-)”)) OR (MM } \\
\text { “Glucocorticoids" OR MM } \\
\text { “Dexamethasone”)) OR (MM “Neurology")) } \\
\text { AND (MM “Genes" OR MM “Alleles" OR }\end{array}$ & & \\
\hline S3 & $\begin{array}{l}\text { MM “CLOCK Gene" OR MM “Immediate } \\
\text { Early Genes" OR MM “Quantitative Trait } \\
\text { Loci” OR MM “Genetics" OR MM } \\
\text { “Behavioral Genetics" OR MM “Epigenetics” } \\
\text { OR MM “Eugenics" OR MM “Genetic }\end{array}$ & $\begin{array}{l}\text { Expanders-Apply equivalent } \\
\text { subjects } \\
\text { Search modes-Boolean/Phrase }\end{array}$ & $\begin{array}{l}\text { Interface-EBSCOhost Research } \\
\text { Databases } \\
\text { Search Screen-Advanced Search } \\
\text { Database-APA PsycInfo }\end{array}$ \\
\hline & Engineering” OR MM “Genetic Processes” & & \\
\hline & OR MM “Genomics" OR MM “Optogenetics” & & \\
\hline & $\begin{array}{c}\text { OR MM “Pharmacogenetics” OR MM } \\
\text { “Population Genetics")) OR (MM } \\
\text { “Gastrointestinal Microbiota”) }\end{array}$ & & \\
\hline S2 & $\begin{array}{l}\text { MM “Major Depression" OR MM “Anaclitic } \\
\text { Depression" OR MM “Dysthymic Disorder" } \\
\text { OR MM “Endogenous Depression" OR MM } \\
\text { "Late Life Depression" OR MM “Postpartum } \\
\text { Depression" OR MM “Reactive Depression" } \\
\text { OR MM “Recurrent Depression" OR MM } \\
\text { “Treatment Resistant Depression" }\end{array}$ & $\begin{array}{l}\text { Expanders-Apply equivalent } \\
\text { subjects } \\
\text { Search modes-Boolean/Phrase }\end{array}$ & $\begin{array}{l}\text { Interface-EBSCOhost Research } \\
\text { Databases } \\
\text { Search Screen-Advanced Search } \\
\text { Database-APA PsycInfo }\end{array}$ \\
\hline S1 & TI caus* n3 (depression or depressive) & $\begin{array}{l}\text { Expanders-Apply equivalent } \\
\text { subjects } \\
\text { Search modes-Boolean/Phrase }\end{array}$ & $\begin{array}{l}\text { Interface-EBSCOhost Research } \\
\text { Databases } \\
\text { Search Screen-Advanced Search } \\
\text { Database-APA PsycInfo }\end{array}$ \\
\hline
\end{tabular}




\section{Scopus}

(TITLE (depression OR “Depressive Disorder") AND TITLE ("Social Determinants of Health" OR tryptophan OR glucocorticoids OR neurology OR genes OR neurogenesis OR "Neuronal Plasticity" OR kynurenine OR genetics OR "Neurogenic Inflammation" OR “Gastrointestinal Microbiome" OR "Genome-Wide Association Study" OR "Gene-Environment Interaction" OR aetiology OR etiology)) OR TITLE (cause* W/3 (depression OR depressive)).

\section{References}

1. World Health Organization. Depression. 2021. Available online: https://www.who.int/news-room/fact-sheets/detail/ depression (accessed on 8 August 2020).

2. Global Health Data Exchange. GBD Results Tool. 2019. Available online: http://ghdx.healthdata.org/gbd-results-tool?params= gbd-api-2019-permalink/d780dffbe8a381b25e1416884959e88b (accessed on 8 August 2020).

3. Kessler, R.C. The costs of depression. Psychiatr. Clin. North Am. 2012, 35, 1-14. [CrossRef]

4. Gilman, S.E.; Sucha, E.; Kingsbury, M.; Horton, N.J.; Murphy, J.M.; Colman, I. Depression and mortality in a longitudinal study: 1952-2011. Can. Med. Assoc. J. 2017, 189, E1304-E1310. [CrossRef]

5. PPinquart, M.; Duberstein, P. Depression and cancer mortality: A meta-analysis. Psychol. Med. 2010, 40, 1797-1810. [CrossRef]

6. McHugh, K.R.; Weiss, R.D. Alcohol Use Disorder and Depressive Disorders. Alcohol Res. 2019, 40, arcr.v40.1.01. [CrossRef]

7. Dhar, A.K.; Barton, D.A. Depression and the Link with Cardiovascular Disease. Front. Psychiatry 2016, 7, 33. [CrossRef]

8. Penn, E.; Tracy, D.K. The drugs don't work? antidepressants and the current and future pharmacological management of depression. Ther. Adv. Psychopharmacol. 2012, 2, 179-188. [CrossRef]

9. Arroll, B.; Macgillivray, S.; Ogston, S.; Reid, I.; Sullivan, F.; Williams, B.; Crombie, I. Efficacy and tolerability of tricyclic antidepressants and SSRIs compared with placebo for treatment of depression in primary care: A meta-analysis. Ann. Fam. Med. 2005, 3, 449-456. [CrossRef] [PubMed]

10. Khawam, E.A.; Laurencic, G.; Malone, D.A., Jr. Side effects of antidepressants: An overview. Clevel. Clin. J. Med. 2006, 73, 351-353. [CrossRef]

11. Beeder, L.A.; Samplaski, M.K. Effect of antidepressant medications on semen parameters and male fertility. Int. J. Urol. 2019, 27, 39-46. [CrossRef]

12. Fava, M. Weight gain and antidepressants. J. Clin. Psychiatry 2000, 61 (Suppl. S11), 37-41.

13. Machado-Vieira, R.; Salvadore, G.; Luckenbaugh, D.A.; Manji, H.K.; Zarate, C.A., Jr. Rapid onset of antidepresssant action: A new paradigm in the research and treatment of major depressive disorder. J Clin Psychiatry 2008, 69, 946-958. [CrossRef]

14. Kirsch, I.; Deacon, B.J.; Huedo-Medina, T.B.; Scoboria, A.; Moore, T.J.; Johnson, B.T. Initial severity and antidepressant benefits: A meta-analysis of data submitted to the Food and Drug Administration. PLoS Med. 2008, 5, e45. [CrossRef]

15. Kendall, K.M.; Van Assche, E.; Andlauer, T.F.M.; Choi, K.W.; Luykx, J.J; Schulte, E.C.; Lu, Y. The genetic basis of major depression. Psychol. Med. 2021, 51, 2217-2230. [CrossRef]

16. Sahoo, S.; Malhotra, S. Antecedents of depression in children and adolescents. Ind. Psychiatry J. 2018, 27, 11-16. [CrossRef]

17. Robertson, E.; Grace, S.; Wallington, T.; Stewart, D.E. Antenatal risk factors for postpartum depression: A synthesis of recent literature. Gen. Hosp. Psychiatry 2004, 26, 289-295. [CrossRef]

18. Tricco, A.C.; Lillie, E.; Zarin, W.; O’Brien, K.K.; Colquhoun, H.; Levac, D.; Moher, D.; Peters, M.D.; Horsley, T.; Weeks, L.; et al. PRISMA Extension for Scoping Reviews (PRISMA-ScR): Checklist and Explanation. Ann. Intern. Med. 2018, 169, 467-473. [CrossRef]

19. Wright, S.; Strunk, A.; Garg, A. New-onset depression among children, adolescents, and adults with hidradenitis suppurativa. J. Am. Acad. Dermatol. 2020, 83, 1360-1366. [CrossRef]

20. Rathbun, A.M.; Shardell, M.D.; Ryan, A.S.; Yau, M.S.; Gallo, J.J.; Schuler, M.S.; Stuart, E.A.; Hochberg, M.C. Association between disease progression and depression onset in persons with radiographic knee osteoarthritis. Rheumatology 2020, 59, 3390-3399. [CrossRef]

21. Min, J.; Yorgason, J.B.; Fast, J.; Chudyk, A. The Impact of Spouse's Illness on Depressive Symptoms: The Roles of Spousal Caregiving and Marital Satisfaction. J. Gerontol. Ser. B 2019, 75, 1548-1557. [CrossRef]

22. Medeiros, G.C.; Roy, D.; Kontos, N.; Beach, S.R. Post-stroke depression: A 2020 updated review. Gen. Hosp. Psychiatry 2020, 66, 70-80. [CrossRef] [PubMed]

23. Lansner, M.W.; Jakobsen, K.K.; Jensen, J.S.; Sandsten, K.E.; Grønhøj, C.; Von Buchwald, C. Development of depression in patients with oral cavity cancer: A systematic review. Acta Oto-Laryngologica 2020, 140, 876-881. [CrossRef]

24. Hughes, F.M., Jr.; Hirshman, N.A.; Malick, H.A.; White, S.W.; Jin, H.; Harper, S.N.; Purves, J.T. A possible mechanism underlying mood disorders associated with LUTS: Chronic bladder outlet obstruction causes NLRP3-dependent inflammation in the hippocampus and depressive behavior in rats. Neurourol. Urodyn. 2020, 39, 1700-1707. [CrossRef]

25. Fang, Y.; Qin, T.; Liu, W.; Ran, L.; Yang, Y.; Huang, H.; Pan, D.; Wang, M. Cerebral Small-Vessel Disease and Risk of Incidence of Depression: A Meta-Analysis of Longitudinal Cohort Studies. J. Am. Heart Assoc. 2020, 9, e016512. [CrossRef] [PubMed]

26. Chen, P.-W.; Liu, P.P.-S.; Lin, S.-M.; Wang, J.-H.; Huang, H.-K.; Loh, C.-H. Cataract and the increased risk of depression in general population: A 16-year nationwide population-based longitudinal study. Sci. Rep. 2020, 10, 13421. [CrossRef] 
27. Almazan, A.N.; Weisholtz, D.S.; Almeida, M. Stroke, Epilepsy, and Antiepileptic Drugs as the Etiology of Major Depressive Disorder: A Case Report and Review. Prim. Care Companion CNS Disord. 2020, 2, 19br02564. [CrossRef]

28. Xue, Z.; Wang, Y.; Wang, L.; Shen, L.; Zhang, A.; Pan, P.; Wang, H.; Dou, J.; Guo, X.; Lv, Y.; et al. Analysis of Influencing Factors of Poststroke Depression: Is Higher Body Mass Index Always a Risk Factor of Poststroke Depression? J. Nerv. Ment. Dis. 2019, 207, 203-208. [CrossRef]

29. Su, J.; Wang, J.; Ma, Y.; Li, Q.; Yang, Y.; Huang, L.; Wang, H.; Li, H.; Wang, Z.; Tong, J.; et al. Inflammation associated with chronic heart failure leads to enhanced susceptibility to depression. FEBS J. 2019, 286, 2769-2786. [CrossRef]

30. Rhee, S.J.; Kim, E.Y.; Kim, S.W.; Kim, S.H.; Lee, H.J.; Yoon, D.H.; Ahn, Y.M. Longitudinal study of the relationship between lower urinary tract symptoms and depressive symptoms. J. Psychosom. Res. 2019, 116, 100-105. [CrossRef]

31. Meng, L.; Li, J.; Cheng, Y.; Wei, T.; Du, Y.; Peng, S. Dysmenorrhea increased the risk of postpartum depression in Chinese Han parturients. Sci. Rep. 2019, 9, 16579. [CrossRef] [PubMed]

32. Mendes-Chiloff, C.L.; Lima, M.C.P.; Torres, A.R.; Santos, J.L.F.; Duarte, Y.O.; Lebrao, M.L.; Cerqueira, A.T.D.A.R. Depressive Symptoms among the Elderly in Sao Paulo city, Brazil: Prevalence and Associated Factors (SABE Study). Rev. Bras. De Epidemiol. 2019, 21 (Suppl. S2), e180014.

33. Malmir, H.; Mirzababaei, A.; Moradi, S.; Rezaei, S.; Mirzaei, K.; Dadfarma, A. Metabolically healthy status and BMI in relation to depression: A systematic review of observational studies. Diabetes Metab. Syndr. Clin. Res. Rev. 2019, 13, 1099-1103. [CrossRef]

34. Lin, S.; Gao, T.; Sun, C.; Jia, M.; Liu, C.; Ma, A. The association between functional dyspepsia and depression: A meta-analysis of observational studies. Eur. J. Gastroenterol. Hepatol. 2019, 31, 911-918. [CrossRef]

35. Brown, P.J.; Brennan, N.; Ciarleglio, A.; Chen, C.; Garcia, C.M.; Gomez, S.; Roose, S.P.; Rutherford, B.R.; Simonsick, E.M.; Spencer, R.G.; et al. Declining Skeletal Muscle Mitochondrial Function Associated with Increased Risk of Depression in Later Life. Am. J. Geriatr. Psychiatry 2019, 27, 963-971. [CrossRef]

36. Arafa, A.; Dong, J.-Y. Gestational diabetes and risk of postpartum depressive symptoms: A meta-analysis of cohort studies. J. Affect. Disord. 2019, 253, 312-316. [CrossRef]

37. Xuan, L.; Zhao, Z.; Jia, X.; Hou, Y.; Wang, T.; Li, M.; Lu, J.; Xu, Y.; Chen, Y.; Qi, L.; et al. Type 2 diabetes is causally associated with depression: A Mendelian randomization analysis. Front. Med. 2018, 12, 678-687. [CrossRef]

38. Wilson, L.; Pandeya, N.; Byles, J.; Mishra, G. Hysterectomy and incidence of depressive symptoms in midlife women: The Australian Longitudinal Study on Women's Health. Epidemiol. Psychiatr. Sci. 2018, 27, 381-392. [CrossRef]

39. Luo, Y.; Zhu, D.; Shi, X.; Nicholas, S.; He, P. Education as a moderator in the effect of diabetes on depressive symptoms in Chinese middle-aged and older adults: A population-based longitudinal study. J. Affect. Disord. 2018, 240, 41-47. [CrossRef]

40. Liu, J.-M.; Chiu, F.-H.; Liu, Y.-P.; Chen, S.-P.; Chan, H.-H.; Yang, J.-J.; Chang, F.-W.; Hsu, R.-J. Antepartum urinary tract infection and postpartum depression in Taiwan-A nationwide population-based study. BMC Pregnancy Childbirth 2018, 18, 79. [CrossRef]

41. Iliadis, S.I.; Axfors, C.; Johansson, S.; Skalkidou, A.; Mulic-Lutvica, A. Women with prolonged nausea in pregnancy have increased risk for depressive symptoms postpartum. Sci. Rep. 2018, 8, 15796. [CrossRef]

42. Hosseini, S.R.; Zabihi, A.; Ebrahimi, S.H.; Amiri, S.R.J.; Kheirkhah, F.; Bijani, A. The Prevalence of Anemia and its Association with Depressive Symptoms among Older Adults in North of Iran. J. Res. Health Sci. 2018, 18, e00431. [PubMed]

43. Greenwood, E.A.; Pasch, L.A.; Cedars, M.I.; Legro, R.S.; Eisenberg, E.; Huddleston, H.G. Insulin resistance is associated with depression risk in polycystic ovary syndrome. Fertil. Steril. 2018, 110, 27-34. [CrossRef]

44. A Graham, E.; Thomson, K.H.; Bambra, C.L. The association between diabetes and depressive symptoms varies by quality of diabetes care across Europe. Eur. J. Public Health 2018, 28, 872-878. [CrossRef]

45. Fan, C.-Y.; Chao, H.-L.; Lin, C.-S.; Huang, W.-Y.; Chen, C.-M.; Lin, K.-T.; Lin, C.-L.; Kao, C.-H. Risk of depressive disorder among patients with head and neck cancer: A nationwide population-based study. Head Neck 2017, 40, 312-323. [CrossRef]

46. Dayan, F.; Javadifar, N.; Tadayon, M.; Malehi, A.S.; Sani, H.K. The Relationship between Gestational Weight Gain and Postpartum Depression in Normal and Overweight Pregnant Women. J. Pregnancy 2018, 2018, 9315320. [CrossRef]

47. Clevesy, M.A.; Gatlin, T.K.; Strebel, K.T. Is There a Relationship Between Gestational Diabetes and Perinatal Depression? MCN Am. J. Matern. Child Nurs. 2018, 43, 206-212. [CrossRef]

48. Chen, Y.-Y.; Lai, Y.-J.; Wang, J.-P.; Shen, Y.-C.; Wang, C.-Y.; Chen, H.-H.; Hu, H.-Y.; Chou, P. The association between glaucoma and risk of depression: A nationwide population-based cohort study. BMC Ophthalmol. 2018, 18, 146. [CrossRef]

49. Bertoni, M.; Maggi, S.; Manzato, E.; Veronese, N.; Weber, G. Depressive symptoms and muscle weakness: A two-way relation? Exp. Gerontol. 2018, 108, 87-91. [CrossRef]

50. Varela, P.; Spyropoulou, A.C.; Kalogerakis, Z.; Vousoura, E.; Moraitou, M.; Zervas, I.M. Association between gestational diabetes and perinatal depressive symptoms: Evidence from a Greek cohort study. Prim. Health Care Res. Dev. 2017, 18, 441-447. [CrossRef]

51. Modalsli, E.H.; Snekvik, I.; Romundstad, P.R.; Naldi, L.; Saunes, M.; O Åsvold, B. The association between the clinical diversity of psoriasis and depressive symptoms: The HUNT Study, Norway. J. Eur. Acad. Dermatol. Venereol. 2017, 31, 2062-2068. [CrossRef]

52. Lee, J.; Jang, S.-N.; Cho, S.-I. Gender differences in the trajectories and the risk factors of depressive symptoms in later life. Int. Psychogeriatr. 2017, 29, 1495-1505. [CrossRef]

53. Ha, H.; Han, C.; Kim, B. Can Obesity Cause Depression? A Pseudo-panel Analysis. J. Prev. Med. Public Health/Yebang Uihakhoe Chi 2017, 50, 262-267.

54. Groger, U. Causes of Depression in Sarcoidosis. Dtsch. Aerzteblatt Online 2017, 114, 120. [CrossRef]

55. Babkair, L.A. Risk Factors for Poststroke Depression: An Integrative Review. J. Neurosci. Nurs. 2017, 49, 73-84. [CrossRef] 
56. Andreeva, V.A.; Assmann, K.E.; Adjibade, M.; Lemogne, C.; Hercberg, S.; Galan, P.; Kesse-Guyot, E. Dyslipidemia as a potential moderator of the association between hearing loss and depressive symptoms. J. Nutr. Health Aging 2017, 21, 1291-1298. [CrossRef]

57. Zhang, R.; Jia, J.; Zhang, D.; Zhao, X. Association between fatigue and depressive symptoms among kidney transplantation recipients: The mediating role of rumination. J. Adv. Nurs. 2019, 75, 3602-3608. [CrossRef]

58. Wang, H.; Huang, B.; Wang, W.; Li, J.; Chen, Y.; Flynn, T.; Zhao, M.; Zhou, Z.; Lin, X.; Zhang, Y.; et al. High urea induces depression and LTP impairment through mTOR signalling suppression caused by carbamylation. EBioMedicine 2019, 48, 478-490. [CrossRef]

59. Liang, Y.; Chen, Y.-K.; Liu, Y.-L.; Mok, V.C.; Ungvari, G.S.; Chu, W.C.; Tang, W.-K.; Kim, J.S.; Kim, J.-M. Exploring causal pathways linking cerebral small vessel diseases burden to poststroke depressive symptoms with structural equation model analysis. $J$. Affect. Disord. 2019, 253, 218-223. [CrossRef]

60. Kahl, K.G.; Stapel, B.; Frieling, H. Link between depression and cardiovascular diseases due to epigenomics and proteomics: Focus on energy metabolism. Prog. Neuro-Psychopharmacol. Biol. Psychiatry 2018, 89, 146-157. [CrossRef]

61. Gabrys, R.L.; Dixon, K.; Holahan, M.R.; Anisman, H. Self-Reported Mild Traumatic Brain Injuries in Relation to Rumination and Depressive Symptoms: Moderating Role of Sex Differences and a Brain-Derived Neurotrophic Factor Gene Polymorphism. Clin. J. Sport Med. 2019, 29, 494-499. [CrossRef]

62. Frangou, S.; Shirali, M.; Adams, M.J.; Howard, D.M.; Gibson, J.; Hall, L.S.; Smith, B.H.; Padmanabhan, S.; Murray, A.D.; Porteous, D.J.; et al. Insulin resistance: Genetic associations with depression and cognition in population based cohorts. Exp. Neurol. 2019, 316, 20-26. [CrossRef]

63. Cadden, M.H.; Guty, E.T.; Arnett, P.A. Cognitive Reserve Attenuates the Effect of Disability on Depression in Multiple Sclerosis. Arch. Clin. Neuropsychol. 2018, 34, 495-502. [CrossRef] [PubMed]

64. Schachter, J.; Martel, J.; Lin, C.-S.; Chang, C.-J.; Wu, T.-R.; Lu, C.-C.; Ko, Y.-F.; Lai, H.-C.; Ojcius, D.M.; Young, J.D. Effects of obesity on depression: A role for inflammation and the gut microbiota. Brain Behav. Immun. 2018, 69, 1-8. [CrossRef]

65. Gariballa, S.; Alessa, A. Association between muscle function, cognitive state, depression symptoms and quality of life of older people: Evidence from clinical practice. Aging Clin. Exp. Res. 2017, 30, 351-357. [CrossRef] [PubMed]

66. Trindade, I.A.; Ferreira, C.; Moura-Ramos, M.; Pinto-Gouveia, J. An 18-month study of the effects of IBD symptomatology and emotion regulation on depressed mood. Int. J. Color. Dis. 2017, 32, 651-660. [CrossRef] [PubMed]

67. Vallerand, I.; Lewinson, R.; Parsons, L.; Lowerison, M.; Frolkis, A.; Kaplan, G.; Barnabe, C.; Bulloch, A.; Patten, S. Risk of depression among patients with acne in the U.K.: A population-based cohort study. Br. J. Dermatol. 2018, 178, e194-e195. [CrossRef]

68. Kvæl, L.A.H.; Bergland, A.; Telenius, E.W. Associations between physical function and depression in nursing home residents with mild and moderate dementia: A cross-sectional study. BMJ Open 2017, 7, e016875. [CrossRef]

69. Roomaney, R.; Kagee, A.; Heylen, S. Biopsychosocial predictors of symptoms of depression in a sample of South African women diagnosed with endometriosis. Health Care Women Int. 2019, 41, 308-329. [CrossRef] [PubMed]

70. Johar, H.; Hoffman, J.; Gunther, J.; Atasoy, S.; Stecher, L.; Spies, M.; Hauner, H.; Ladwig, K.H. Evaluation of antenatal risk factors for postpartum depression: A secondary cohort analysis of the cluster-randomised GeliS trial. BMC Med. 2020, 18, 227. [CrossRef]

71. Miwata, K.; Masuda, T.; Yamaguchi, K.; Sakamoto, S.; Horimasu, Y.; Miyamoto, S.; Nakashima, T.; Iwamoto, H.; Fujitaka, K.; Hamada, H.; et al. Performance status is a risk factor for depression before the diagnosis of lung cancer patients. Intern. Med. 2019, 58, 915-920. [CrossRef]

72. Zhang, J.; Yang, J.; Han, N.; Zhao, X.; Ma, J.; Ban, B.; Zhu, X.; Yang, Y.; Cao, D.; Qiu, X. Dvl3 polymorphism interacts with life events and pro-inflammatory cytokines to influence major depressive disorder susceptibility. Sci. Rep. 2018, 8, 14181. [CrossRef] [PubMed]

73. Zhang, H.-F.; Mellor, D.; Peng, D.-H. Neuroimaging genomic studies in major depressive disorder: A systematic review. CNS Neurosci. Ther. 2018, 24, 1020-1036. [CrossRef]

74. Xiao, X.; Zheng, F.; Chang, H.; Ma, Y.; Yao, Y.-G.; Luo, X.-J.; Li, M. The Gene Encoding Protocadherin 9 (PCDH9), a Novel Risk Factor for Major Depressive Disorder. Neuropsychopharmacology 2017, 43, 1128-1137. [CrossRef]

75. Wigner, P.; Czarny, P.; Synowiec, E.; Bijak, M.; Białek, K.; Talarowska, M.; Galecki, P.; Szemraj, J.; Sliwinski, T. Association between single nucleotide polymorphisms of TPH1 and TPH2 genes, and depressive disorders. J. Cell. Mol. Med. 2018, 22, 1778-1791. [CrossRef]

76. Wigner, P.; Czarny, P.; Synowiec, E.; Białek, K.; Talarowska, M.; Galecki, P.; Szemraj, J.; Sliwinski, T. Variation of genes involved in oxidative and nitrosative stresses in depression. Eur. Psychiatry 2017, 48, 38-48. [CrossRef]

77. Wang, Q.; Shelton, R.C.; Dwivedi, Y. Interaction between early-life stress and FKBP5 gene variants in major depressive disorder and post-traumatic stress disorder: A systematic review and meta-analysis. J. Affect. Disord. 2017, 225, 422-428. [CrossRef]

78. Mekli, K.; Phillips, D.F.; Arpawong, T.E.; Vanhoutte, B.; Tampubolon, G.; Nazroo, J.Y.; Lee, J.; Prescott, C.A.; Stevens, A.; Pendleton, N. Genome-wide scan of depressive symptomatology in two representative cohorts in the United States and the United Kingdom. J. Psychiatr. Res. 2018, 100, 63-70. [CrossRef] [PubMed]

79. Lam, D.; Ancelin, M.-L.; Ritchie, K.; Freak-Poli, R.; Saffery, R.; Ryan, J. Genotype-dependent associations between serotonin transporter gene (SLC6A4) DNA methylation and late-life depression. BMC Psychiatry 2018, 18, 282. [CrossRef]

80. Lam, D.; Ancelin, M.-L.; Ritchie, K.; Saffery, R.; Ryan, J. DNA methylation and genetic variation of the angiotensin converting enzyme (ACE) in depression. Psychoneuroendocrinology 2018, 88, 1-8. [CrossRef] 
81. Gardiner, S.L.; Van Belzen, M.J.; Boogaard, M.W.; Van Roon-Mom, W.M.C.; Rozing, P.; Van Hemert, A.M.; Smit, J.H.; Beekman, A.T.F.; Van Grootheest, G.; Schoevers, R.A.; et al. Large normal-range TBP and ATXN7 CAG repeat lengths are associated with increased lifetime risk of depression. Transl. Psychiatry 2017, 7, e1143. [CrossRef]

82. Ma, J.; Wang, L.; Yang, Y.; Qiao, Z.; Fang, D.; Qiu, X.; Yang, X.; Zhu, X.; He, J.; Pan, H.; et al. GNB3 and CREB1 gene polymorphisms combined with negative life events increase susceptibility to major depression in a Chinese Han population. PLoS ONE 2017, 12, e0170994. [CrossRef]

83. Michalek, J.; Kepa, A.; Vincent, J.; Frissa, S.; Goodwin, L.; Hotopf, M.; Hatch, S.L.; Breen, G.; Powell, T.R. Genetic predisposition to advanced biological ageing increases risk for childhood-onset recurrent major depressive disorder in a large UK sample. $J$. Affect. Disord. 2017, 213, 207-213. [CrossRef]

84. Roy, B.; Dunbar, M.; Shelton, R.C.; Dwivedi, Y. Identification of MicroRNA-124-3p as a Putative Epigenetic Signature of Major Depressive Disorder. Neuropsychopharmacology 2016, 42, 864-875. [CrossRef]

85. Treutlein, J.; Strohmaier, J.; Frank, J.; Witt, S.H.; Rietschel, L.; Forstner, A.J.; Lang, M.; Degenhardt, F.; Dukal, H.; Herms, S.; et al. Association between neuropeptide $\mathrm{Y}$ receptor Y2 promoter variant rs6857715 and major depressive disorder. Psychiatr. Genet. 2017, 27, 34-37. [CrossRef]

86. Machado, F.D.C.; De Souza, L.V.; Rangel, M.; Jara, Z.P.; Franco, M.D.C. Implication of galanin gene rs948854 polymorphism in depressive symptoms in adolescents. Horm. Behav. 2018, 97, 14-17. [CrossRef] [PubMed]

87. Zajączkowska, M.; Talarowska, M.; Szemraj, J.; Gałecki, P. Polymorphism and expression of the DVL3 gene in the etiology of depressive disorder. Psychiatr. Polska 2020, 54, 509-523. [CrossRef] [PubMed]

88. Wang, Y.; Liu, H.; Jiang, Y.; Shi, X.; Shao, Y.; Xu, Z.X. Meta-analysis of 5-hydroxytryptamine transporter gene promoter region polymorphism and post-stroke depression. J. Int. Med. Res. 2020, 48, 0300060520925943. [CrossRef] [PubMed]

89. Wang, X.; Zhang, H.; Cao, X.; Shi, W.; Zhou, X.; Chen, Q.; Ma, K. Gene-disease association study of tumor necrosis factor- $\alpha$ G-308A gene polymorphism with risk of major depressive disorder: A systematic review and meta-analysis. Brain Behav. 2020, 10, e01628. [CrossRef]

90. Wang, X.; Cheng, W.; Zhu, J.; Yin, H.; Chang, S.; Yue, W.; Yu, H. Integrating genome-wide association study and expression quantitative trait loci data identifies NEGR1 as a causal risk gene of major depression disorder. J. Affect. Disord. 2019, 265, 679-686. [CrossRef]

91. Wang, H.Q.; Wang, Z.Z.; Chen, N.H. Advance in relationship between receptor gene abnormality and depression. Yaoxue Xuebao 2020, 55, 384-391.

92. Wang, F.; Yu, S.; Zhou, R.; Mao, R.; Zhao, G.; Guo, X.; Xu, Q.; Chen, J.; Zhang, C.; Fang, Y. Variants in the Upstream Region of the Insulin Receptor Substrate-1 Gene Is Associated with Major Depressive Disorder in the Han Chinese Population. Neuropsychiatr. Dis. Treat. 2020, ume 16, 501-507. [CrossRef]

93. Guleria, K.; Suneja, A.; Sharma, R.; Banerjee, B.D.; Bhatia, M.S.; Chaudhary, N. Association of Placental Tissue Estrogen Receptor Alpha Gene Expression with Postpartum Depression in Women at Risk: A Pilot Study. J. SAFOG DVD 2020, 12, 391-401. [CrossRef]

94. Meyer, T.; Rothe, I.; Staab, J.; Deter, H.-C.; Fangauf, S.V.; Hamacher, S.; Hellmich, M.; Jünger, J.; Ladwig, K.-H.; Michal, M.; et al. Length Polymorphisms in the Angiotensin I-Converting Enzyme Gene and the Serotonin-Transporter-Linked Polymorphic Region Constitute a Risk Haplotype for Depression in Patients with Coronary Artery Disease. Biochem. Genet. 2020, 58, 631-648. [CrossRef] [PubMed]

95. Li, S.; Li, Y.; Li, X.; Liu, J.; Huo, Y.; Wang, J.; Liu, Z.; Li, M.; Luo, X.-J. Regulatory mechanisms of major depressive disorder risk variants. Mol. Psychiatry 2020, 25, 1926-1945. [CrossRef]

96. Gutiérrez-Zotes, A.; Diaz-Pena, R.; Costas, J.; Martorell, L.; Gelabert, E.; Sans, T.; Navines, R.; Albacar, G.; Imaz, M.L.; GarciaEsteve, L.; et al. Interaction between the functional SNP rs2070951 in NR3C2 gene and high levels of plasma corticotropin-releasing hormone associates to postpartum depression. Arch. Women's Ment. Health 2020, 23, 413-420. [CrossRef] [PubMed]

97. Zhong, J.; Li, S.; Zeng, W.; Li, X.; Gu, C.; Liu, J.; Luo, X.-J. Integration of GWAS and brain eQTL identifies FLOT1 as a risk gene for major depressive disorder. Neuropsychopharmacology 2019, 44, 1542-1551. [CrossRef]

98. Zeng, D.; He, S.; Ma, C.; Wen, Y.; Xie, Y.; Zhao, N.; Sun, X.; Wang, D.; Shen, Y.; Yu, Y.; et al. Co-Expression Network Analysis Revealed That the ATP5G1 Gene Is Associated with Major Depressive Disorder. Front. Genet. 2019, 10, 703. [CrossRef] [PubMed]

99. Kong, X.; Miao, Q.; Lu, X.; Zhang, Z.; Chen, M.; Zhang, J.; Zhai, J. The association of endocannabinoid receptor genes (CNR1 and CNR2) polymorphisms with depression: A meta-analysis. Medicine 2019, 98, e17403. [CrossRef]

100. Ding, X.; Yang, Q.; Su, L.; Huang, X.; Zhou, Z. Correlation Between C3435T Locus of ABCB1 Gene and Poststroke Depression in China. DNA Cell Biol. 2019, 38, 808-813. [CrossRef]

101. Avinun, R.; Hariri, A.R. A polygenic score for body mass index is associated with depressive symptoms via early life stress: Evidence for gene-environment correlation. J. Psychiatr. Res. 2019, 118, 9-13. [CrossRef]

102. Rui, H.; Qian, H.; Shi, M.; Zhang, G.; Wang, L. Meta-analysis on the Association Between Norepinephrine Transporter Gene rs2242446, rs5569 Polymorphisms and Risk of Major Depressive Disorder. Arch. Med. Res. 2018, 49, 261-269. [CrossRef]

103. Mossakowska-Wójcik, J.; Orzechowska, A.; Talarowska, M.; Szemraj, J.; Gałecki, P. The importance of TCF4 gene in the etiology of recurrent depressive disorders. Prog. Neuro-Psychopharmacol. Biol. Psychiatry 2018, 80, 304-308. [CrossRef] 
104. Czarny, P.; Wigner, P.; Strycharz, J.; Watala, C.; Swiderska, E.; Synowiec, E.; Galecki, P.; Talarowska, M.; Szemraj, J.; Su, K.-P.; et al. Single-nucleotide polymorphisms of uracil-processing genes affect the occurrence and the onset of recurrent depressive disorder. PeerJ 2018, 6, e5116. [CrossRef]

105. Shin, K.-H.; Jeong, H.C.; Choi, D.-H.; Kim, S.N.; Kim, T.-E. Association of TNF-alpha G-308A gene polymorphism with depression: A meta-analysis. Neuropsychiatr. Dis. Treat. 2017, ume 13, 2661-2668. [CrossRef]

106. Sarubin, N.; Hilbert, S.; Naumann, F.; Zill, P.; Wimmer, A.; Nothdurfter, C.; Rupprecht, R.; Baghai, T.C.; Buhner, M.; Schule, C. The sex-dependent role of the glucocorticoid receptor in depression: Variations in the NR3C1 gene are associated with major depressive disorder in women but not in men. Eur. Arch. Psychiatry Clin. Neurosci. 2017, 267, 123-133.

107. Liu, J.; Zhang, H.-X.; Li, Z.-Q.; Li, T.; Li, J.-Y.; Wang, T.; Li, Y.; Feng, G.-Y.; Shi, Y.-Y.; He, L. The YWHAE gene confers risk to major depressive disorder in the male group of Chinese Han population. Prog. Neuro-Psychopharmacol. Biol. Psychiatry 2017, 77, 172-177. [CrossRef] [PubMed]

108. Gardiner, S.L.; Van Belzen, M.J.; Boogaard, M.W.; Van Roon-Mom, W.M.C.; Rozing, M.P.; Van Hemert, A.M.; Smit, J.H.; Beekman, A.T.F.; Van Grootheest, G.; Schoevers, R.A.; et al. Huntingtin gene repeat size variations affect risk of lifetime depression. Transl. Psychiatry 2017, 7, 1277. [CrossRef]

109. Van Dalfsen, J.H.; Markus, C.R. The involvement of sleep in the relationship between the serotonin transporter gene-linked polymorphic region (5-HTTLPR) and depression: A systematic review. J Affect. Disord 2019, 256, 205-212. [CrossRef] [PubMed]

110. Li, H.; Chang, H.; Song, X.; Liu, W.; Li, L.; Wang, L.; Yang, Y.; Zhang, L.; Li, W.; Zhang, Y.; et al. Integrative analyses of major histocompatibility complex loci in the genome-wide association studies of major depressive disorder. Neuropsychopharmacology 2019, 44, 1552-1561. [CrossRef] [PubMed]

111. Ksinan, A.J.; Vazsonyi, A.T. Genetic and environmental effects on the development of depressive symptoms from adolescence to adulthood in a nationally representative sample. J. Affect. Disord. 2019, 245, 163-173. [CrossRef]

112. Gerring, Z.F.; Gamazon, E.R.; Derks, E.M. A gene co-expression network-based analysis of multiple brain tissues reveals novel genes and molecular pathways underlying major depression. PLoS Genet. 2019, 15, e1008245. [CrossRef]

113. Wigner, P.; Czarny, P.; Synowiec, E.; Bijak, M.; Talarowska, M.; Galecki, P.; Szemraj, J.; Sliwinski, T. Variation of genes encoding KAT1, AADAT and IDO1 as a potential risk of depression development. Eur. Psychiatry 2018, 52, 95-103. [CrossRef]

114. Uchida, S.; Yamagata, H.; Seki, T.; Watanabe, Y. Epigenetic mechanisms of major depression: Targeting neuronal plasticity. Psychiatry Clin. Neurosci. 2017, 72, 212-227. [CrossRef]

115. Shimada, M.; Otowa, T.; Miyagawa, T.; Umekage, T.; Kawamura, Y.; Bundo, M.; Iwamoto, K.; Ikegame, T.; Tochigi, M.; Kasai, K.; et al. An epigenome-wide methylation study of healthy individuals with or without depressive symptoms. J. Hum. Genet. 2018, 63, 319-326. [CrossRef]

116. Kojima, M.; Matsui, K.; Mizui, T. BDNF pro-peptide: Physiological mechanisms and implications for depression. Cell Tissue Res. 2019, 377, 73-79. [CrossRef]

117. Aldoghachi, A.F.; Tor, Y.S.; Redzun, S.Z.; Bin Lokman, K.A.; Razaq, N.A.A.; Shahbudin, A.F.; Badamasi, I.M.; Cheah, P.-S.; Stanslas, J.; Veerakumarasivam, A.; et al. Screening of brain-derived neurotrophic factor (BDNF) single nucleotide polymorphisms and plasma BDNF levels among Malaysian major depressive disorder patients. PLoS ONE 2019, 14, e0211241. [CrossRef]

118. Youssef, M.M.; Underwood, M.D.; Huang, Y.; Hsiung, S.; Liu, Y.; Simpson, N.R.; Bakalian, M.; Rosoklija, G.B.; Dwork, A.J.; Arango, V.; et al. Association of BDNF Val66Met Polymorphism and Brain BDNF Levels with Major Depression and Suicide. Int. J. Neuropsychopharmacol. 2018, 21, 528-538. [CrossRef]

119. Elwood, J.; Murray, E.; Bell, A.; Sinclair, M.; Kernohan, W.G.; Stockdale, J. A systematic review investigating if genetic or epigenetic markers are associated with postnatal depression. J. Affect. Disord. 2019, 253, 51-62. [CrossRef] [PubMed]

120. Duan, K.-M.; Wang, S.-Y.; Yin, J.-Y.; Li, X.; Ma, J.-H.; Huang, Z.-D.; Zhou, Y.-Y.; Yu, H.-Y.; Yang, M.; Zhou, H.-H.; et al. The IDO genetic polymorphisms and postpartum depressive symptoms: An association study in Chinese parturients who underwent cesarean section. Arch. Women's Ment. Health 2018, 22, 339-348. [CrossRef]

121. Dam, H.; Buch, J.O.; Nielsen, A.B.; Weikop, P.; Werge, T.; Jorgensen, M.B. Clinical association to FKBP5 rs1360780 in patients with depression. Psychiatr. Genet. 2019, 29, 220-225. [CrossRef]

122. Border, R.; Johnson, E.C.; Evans, L.M.; Smolen, A.; Berley, N.; Sullivan, P.F.; Keller, M.C. No Support for Historical Candidate Gene or Candidate Gene-by-Interaction Hypotheses for Major Depression Across Multiple Large Samples. Am. J. Psychiatry 2019, 176, 376-387. [CrossRef]

123. Wang, L.; Chen, J.; Li, Z.; Sun, W.; Chen, B.; Li, S.; Li, W.; Lu, D.; Wang, Y.; Shi, Y. Association study of NDST3 gene for schizophrenia, bipolar disorder, major depressive disorder in the Han Chinese population. Am. J. Med. Genet. B Neuropsychiatr. Genet. 2018, 177, 3-9. [CrossRef]

124. Nagy, C.; Vaillancourt, K.; Turecki, G. A role for activity-dependent epigenetics in the development and treatment of major depressive disorder. Genes Brain Behav. 2018, 17, e12446. [CrossRef]

125. Mundorf, A.; Schmitz, J.; Gunturkun, O.; Freund, N.; Ocklenburg, S. Methylation of MORC1: A possible biomarker for depression? J. Psychiatr. Res. 2018, 103, 208-211. [CrossRef]

126. Liu, D.; Ray, B.; Neavin, D.R.; Zhang, J.; Athreya, A.P.; Biernacka, J.M.; Bobo, W.V.; Hall-Flavin, D.K.; Skime, M.K.; Zhu, H. Beta-defensin 1, aryl hydrocarbon receptor and plasma kynurenine in major depressive disorder: Metabolomics-informed genomics. Transl. Psychiatry 2018, 8, 10. [CrossRef] 
127. Lima-Ojeda, J.M.; Rupprecht, R.; Baghai, T.C. Neurobiology of depression: A neurodevelopmental approach. World J. Biol. Psychiatry 2017, 19, 349-359. [CrossRef]

128. Kushner, S.C.; Herzhoff, K.; Vrshek-Schallhorn, S.; Tackett, J.L. Depression in early adolescence: Contributions from relational aggression and variation in the oxytocin receptor gene. Aggress. Behav. 2017, 44, 60-68. [CrossRef]

129. Kitzlerová, E.; Fišar, Z.; Lelková, P.; Jirák, R.; Zvěřová, M.; Hroudová, J.; Manukyan, A.; Martásek, P.; Raboch, J. Interactions Among Polymorphisms of Susceptibility Loci for Alzheimer's Disease or Depressive Disorder. Med. Sci. Monit. 2018, 24, 2599-2619. [CrossRef]

130. Kang, H.-J.; Bae, K.-Y.; Kim, S.-W.; Shin, I.-S.; Kim, H.-R.; Shin, M.-G.; Yoon, J.-S.; Kim, J.-M. Longitudinal associations between glucocorticoid receptor methylation and late-life depression. Prog. Neuro-Psychopharmacol. Biol. Psychiatry 2018, 84, 56-62. [CrossRef]

131. Jesulola, E.; Micalos, P.; Baguley, I.J. Understanding the pathophysiology of depression: From monoamines to the neurogenesis hypothesis model-Are we there yet? Behav. Brain Res. 2018, 341, 79-90. [CrossRef]

132. Hu, J.; Bi, Y.; Shi, L.; Xu, F.; Yuan, F.; Niu, W.; Ren, D.; Guo, Z.; Yang, F.; He, L.; et al. No association of GRIN2A polymorphisms with the major depressive disorder in the Chinese Han origin. Psychiatr. Genet. 2018, 28, 120-121. [CrossRef] [PubMed]

133. Geisler, S.; Sperner-Unterweger, B.; Fuchs, D.; Gostner, J.M. Immunometabolism in the Pathogenesis of Depressive DisordersTherapeutic Considerations. Curr. Top. Med. Chem. 2018, 18, 1408-1415. [CrossRef]

134. Yang, Y.; Fang, M.; Du, X.; Hu, Z. Lucky gene 5-HTTLPR and postpartum depression: A systematic review. Neuro Endocrinol. Lett. 2017, 38, 316-320.

135. Xu, C.; Yang, C.; Zhang, A.; Xu, Y.; Li, X.; Liu, Z.; Liu, S.; Sun, N.; Zhang, K. The interaction of miR-34b/c polymorphisms and negative life events increases susceptibility to major depressive disorder in Han Chinese population. Neurosci. Lett. 2017, 651, 65-71. [CrossRef]

136. Wigner, P.; Czarny, P.; Galecki, P.; Sliwinski, T. Oxidative and Nitrosative Stress as Well As The Tryptophan Catabolites Pathway In Depressive Disorders. Psychiatr. Danub. 2017, 29, 394-400. [CrossRef]

137. Park, M.; Kim, S.A.; Yee, J.; Shin, J.; Lee, K.Y.; Joo, E.-J. Significant role of gene-gene interactions of clock genes in mood disorder. J. Affect. Disord. 2019, 257, 510-517. [CrossRef]

138. Liu, Y.; Fan, P.; Zhang, S.; Wang, Y.; Liu, D. Prioritization and comprehensive analysis of genes related to major depressive disorder. Mol. Genet. Genom. Med. 2019, 7, e659. [CrossRef]

139. Fabbri, C.; Corponi, F.; Souery, D.; Kasper, S.; Montgomery, S.; Zohar, J.; Rujescu, D.; Mendlewicz, J.; Serretti, A. The Genetics of Treatment-Resistant Depression: A Critical Review and Future Perspectives. Int. J. Neuropsychopharmacol. 2018, $22,93-104$. [CrossRef]

140. Brouillard, C.; Brendgen, M.; Vitaro, F.; Dionne, G.; Boivin, M. Links Between the Mother-Adolescent and Father-Adolescent Relationships and Adolescent Depression: A Genetically Informed Study. J. Clin. Child Adolesc. Psychol. 2016, 47, S397-S408. [CrossRef]

141. Gulyaeva, N.V. Interplay between brain BDNF and glutamatergic systems: A brief state of the evidence and association with the pathogenesis of depression. Biochem. 2017, 82, 301-307. [CrossRef] [PubMed]

142. Kuhlmann, S.L.; Tschorn, M.; Arolt, V.; Beer, K.; Brandt, J.; Grosse, L.; Haverkamp, W.; Müller-Nordhorn, J.; Rieckmann, N.; Waltenberger, J.; et al. Serum brain-derived neurotrophic factor and depressive symptoms in coronary heart disease patients: Role of cognitive functions. Psychoneuroendocrinology 2017, 79, 175-176. [CrossRef]

143. Qiao, H.; An, S.-C.; Xu, C.; Ma, X.-M. Role of proBDNF and BDNF in dendritic spine plasticity and depressive-like behaviors induced by an animal model of depression. Brain Res. 2017, 1663, 29-37. [CrossRef]

144. He, S.-C.; Wu, S.; Wang, C.; Du, X.-D.; Yin, G.; Jia, Q.; Zhang, Y.; Wang, L.; Soares, J.C.; Zhang, X.Y. Interaction between job stress and the BDNF Val66Met polymorphism affects depressive symptoms in Chinese healthcare workers. J. Affect. Disord. 2018, 236, 157-163. [CrossRef]

145. Hing, B.; Sathyaputri, L.; Potash, J.B. A comprehensive review of genetic and epigenetic mechanisms that regulate BDNF expression and function with relevance to major depressive disorder. Am. J. Med. Genet. B Neuropsychiatr Genet. 2018, 177, 143-167. [CrossRef]

146. Chen, J.; Vitetta, L. Mitochondria could be a potential key mediator linking the intestinal microbiota to depression. J. Cell. Biochem. 2019, 121, 17-24. [CrossRef]

147. Valles-Colomer, M.; Falony, G.; Darzi, Y.; Tigchelaar, E.F.; Wang, J.; Tito, R.Y.; Schiweck, C.; Kurilshikov, A.; Joossens, M.; Wijmenga, C.; et al. The neuroactive potential of the human gut microbiota in quality of life and depression. Nat. Microbiol. 2019, 4, 623-632. [CrossRef] [PubMed]

148. Stower, H. Depression linked to the microbiome. Nat. Med. 2019, 25, 358. [CrossRef]

149. Song, J.; Ma, W.; Gu, X.; Zhao, L.; Jiang, J.; Xu, Y.; Zhang, L.; Zhou, M.; Yang, L. Metabolomic signatures and microbial community profiling of depressive rat model induced by adrenocorticotrophic hormone. J. Transl. Med. 2019, 17, 224. [CrossRef]

150. Sanders, A.; Rackers, H.; Kimmel, M. A role for the microbiome in mother-infant interaction and perinatal depression. Int. Rev. Psychiatry 2019, 31, 280-294. [CrossRef]

151. Ma, W.; Song, J.; Wang, H.; Shi, F.; Zhou, N.; Jiang, J.; Xu, Y.; Zhang, L.; Yang, L.; Zhou, M. Chronic paradoxical sleep deprivationinduced depression-like behavior, energy metabolism and microbial changes in rats. Life Sci. 2019, 25, 88-97. [CrossRef] 
152. Lv, W.-J.; Wu, X.-L.; Chen, W.-Q.; Li, Y.-F.; Zhang, G.-F.; Chao, L.-M.; Zhou, J.-H.; Guo, A.; Liu, C.; Guo, S.-N. The Gut Microbiome Modulates the Changes in Liver Metabolism and in Inflammatory Processes in the Brain of Chronic Unpredictable Mild Stress Rats. Oxidative Med. Cell. Longev. 2019, 2019, 1-14. [CrossRef]

153. Kuo, P.-H.; Chung, Y.-C.E. Moody microbiome: Challenges and chances. J. Formos. Med Assoc. 2018, 118 (Suppl. S1), S42-S54. [CrossRef]

154. Kelly, J.R.; O’Keane, V.O.; Cryan, J.F.; Clarke, G.; Dinan, T.G. Mood and Microbes: Gut to Brain Communication in Depression. Gastroenterol. Clin North Am. 2019, 48, 389-405. [CrossRef]

155. Jianguo, L.; Xueyang, J.; Cui, W.; Changxin, W.; Xuemei, Q. Altered gut metabolome contributes to depression-like behaviors in rats exposed to chronic unpredictable mild stress. Transl. Psychiatry 2019, 9, 40. [CrossRef]

156. Chung, Y.-C.E.; Chen, H.-C.; Chou, H.-C.L.; Chen, I.-M.; Lee, M.-S.; Chuang, L.-C.; Liu, Y.-W.; Lu, M.-L.; Chen, C.-H.; Wu, C.-S.; et al. Exploration of microbiota targets for major depressive disorder and mood related traits. J. Psychiatr. Res. 2019, 111, 74-82. [CrossRef] [PubMed]

157. Zalar, B.; Haslberger, A.; Peterlin, B. The Role of Microbiota in Depression-A brief review. Psychiatr. Danub. 2018, 30, 136-141. [CrossRef]

158. Winter, G.; Hart, R.A.; Charlesworth, R.; Sharpley, C. Gut microbiome and depression: What we know and what we need to know. Rev. Neurosci. 2018, 29, 629-643. [CrossRef]

159. Guida, F.; Turco, F.; Iannotta, M.; De Gregorio, D.; Palumbo, I.; Sarnelli, G.; Furiano, A.; Napolitano, F.; Boccella, S.; Luongo, L.; et al. Antibiotic-induced microbiota perturbation causes gut endocannabinoidome changes, hippocampal neuroglial reorganization and depression in mice. Brain Behav. Immun. 2018, 67, 230-245. [CrossRef]

160. Yang, C.; Fujita, Y.; Ren, Q.; Ma, M.; Dong, C.; Hashimoto, K. Bifidobacterium in the gut microbiota confer resilience to chronic social defeat stress in mice. Sci. Rep. 2017, 7, srep45942. [CrossRef]

161. Koopman, M.; El Aidy, S. Depressed gut? The microbiota-diet-inflammation trialogue in depression. Curr. Opin. Psychiatry 2017, 30, 369-377. [CrossRef]

162. Rivet-Noor, C.; Gaultier, A. The Role of Gut Mucins in the Etiology of Depression. Front. Behav. Neurosci. 2020, $14,592388$. [CrossRef]

163. Ramírez-Carrillo, E.; Gaona, O.; Nieto, J.; Sánchez-Quinto, A.; Cerqueda-García, D.; Falcón, L.I.; Rojas-Ramos, O.A.; GonzálezSantoyo, I. Disturbance in human gut microbiota networks by parasites and its implications in the incidence of depression. Sci. Rep. 2020, 10, 3680. [CrossRef]

164. Anderson, G. Linking the biological underpinnings of depression: Role of mitochondria interactions with melatonin, inflammation, sirtuins, tryptophan catabolites, DNA repair and oxidative and nitrosative stress, with consequences for classification and cognition. Prog. Neuro-Psychopharmacol. Biol. Psychiatry 2018, 80, 255-266. [CrossRef]

165. Simkin, D.R. Microbiome and Mental Health, Specifically as It Relates to Adolescents. Curr. Psychiatry Rep. 2019, 21, 93. [CrossRef]

166. Stevens, B.R.; Goel, R.; Seungbum, K.; Richards, E.M.; Holbert, R.C.; Pepine, C.; Raizada, M.K. Increased human intestinal barrier permeability plasma biomarkers zonulin and FABP2 correlated with plasma LPS and altered gut microbiome in anxiety or depression. Gut 2017, 67, 1555-1557. [CrossRef]

167. Gong, X.; Huang, C.; Yang, X.; Mao, Q.; Zeng, L.; Zheng, P.; Pu, J.; Chen, J.; Wang, H.; Xu, B.; et al. Proteomic analysis of the intestine reveals SNARE-mediated immunoregulatory and amino acid absorption perturbations in a rat model of depression. Life Sci. 2019, 234, 116778. [CrossRef]

168. Slykerman, R.F.; Thompson, J.; Waldie, K.; Murphy, R.; Wall, C.; Mitchell, E.A. Antibiotics in the first year of life and subsequent neurocognitive outcomes. Acta Paediatr. 2016, 106, 87-94. [CrossRef] [PubMed]

169. Madison, A.A.; Andridge, R.; Padin, A.C.; Wilson, S.; Bailey, M.T.; Alfano, C.M.; Povoski, S.P.; Lipari, A.M.; Agnese, D.M.; Carson, W.E.; et al. Endotoxemia coupled with heightened inflammation predicts future depressive symptoms. Psychoneuroendocrinology 2020, 122, 104864. [CrossRef]

170. Lu, H.; Surkan, P.J.; Irwin, M.R.; Treisman, G.J.; Breen, E.C.; Sacktor, N.; Stall, R.; Wolinsky, S.M.; Jacobson, L.P.; Abraham, A.G. Inflammation and Risk of Depression in HIV: Prospective Findings from the Multicenter AIDS Cohort Study. Am. J. Epidemiol. 2019, 188, 1994-2003. [CrossRef]

171. Leonard, B.E. Inflammation and depression: A causal or coincidental link to the pathophysiology? Acta Neuropsychiatr. 2018, 30, 1-16. [CrossRef]

172. Cheng, L.-S.; Tu, W.-J.; Shen, Y.; Zhang, L.-J.; Ji, K. Combination of High-Sensitivity C-Reactive Protein and Homocysteine Predicts the Post-Stroke Depression in Patients with Ischemic Stroke. Mol. Neurobiol. 2017, 55, 2952-2958. [CrossRef]

173. Kang, H.J.; Bae, K.Y.; Kim, S.W.; Shin, I.S.; Hong, Y.J.; Ahn, Y.; Jeong, M.H.; Yoon, J.S.; Kim, J.M. Relationship between interleukin1 beta and depressive disorder after acute coronary syndrome. Prog. Neuro-Psychopharmacol. Biol. Psychiatry 2017, 72, 55-59. [CrossRef] [PubMed]

174. Zhao, G.; Liu, X. Neuroimmune Advance in Depressive Disorder. Adv. Exp. Med. Biol. 2019, 85-98. [CrossRef]

175. Moulton, C.D.; Pavlidis, P.; Norton, C.; Norton, S.; Pariante, C.; Hayee, B.; Powell, N. Depressive symptoms in inflammatory bowel disease: An extraintestinal manifestation of inflammation? Clin. Exp. Immunol. 2019, 197, 308-318. [CrossRef] [PubMed]

176. Inserra, A.; Mastronardi, C.A.; Rogers, G.; Licinio, J.; Wong, M.-L. Neuroimmunomodulation in Major Depressive Disorder: Focus on Caspase 1, Inducible Nitric Oxide Synthase, and Interferon-Gamma. Mol. Neurobiol. 2018, 56, 4288-4305. [CrossRef] 
177. Hüfner, K.; Fuchs, D.; Blauth, M.; Sperner-Unterweger, B. How acute and chronic physical disease may influence mental health -An Analysis of neurotransmitter precursor amino acid levels. Psychoneuroendocrinology 2019, 106, 95-101. [CrossRef]

178. Barone, P. The 'Yin' and the 'Yang' of the kynurenine pathway: Excitotoxicity and neuroprotection imbalance in stress-induced disorders. Behav. Pharm. 2019, 30, 163-186. [CrossRef]

179. Zang, X.; Zheng, X.; Hou, Y.; Hu, M.; Wang, H.; Bao, X.; Zhou, F.; Wang, G.; Hao, H. Regulation of proinflammatory monocyte activation by the kynurenine-AhR axis underlies immunometabolic control of depressive behavior in mice. FASEB J. 2018, 32, 1944-1956. [CrossRef]

180. Ramírez, L.A.; Perez-Padilla, E.A.; Garcia-Oscos, F.; Salgado, H.; Atzori, M.; Pineda, J.C. A new theory of depression based on the serotonin/kynurenine relationship and the hypothalamicpituitary- adrenal axis. Biomedica 2018, 38, 437-450. [CrossRef] [PubMed]

181. Haverkamp, G.L.; Loosman, W.L.; Schouten, R.W.; Franssen, C.; Kema, I.P.; Van Diepen, M.; Dekker, F.; Siegert, C.E.; Honig, A. Differences in the association of inflammation and tryptophan with depressive symptoms between white and non-white chronic dialysis patients. Gen. Hosp. Psychiatry 2018, 50, 76-82. [CrossRef] [PubMed]

182. Pariante, C.M. Why are depressed patients inflamed? A reflection on 20 years of research on depression, glucocorticoid resistance and inflammation. Eur. Neuropsychopharmacol. 2017, 27, 554-559. [CrossRef] [PubMed]

183. Haverkamp, G.L.; Loosman, W.L.; Franssen, C.; Kema, I.P.; Van Diepen, M.; Dekker, F.; Honig, A.; Siegert, C.E. The role of tryptophan degradation in the association between inflammatory markers and depressive symptoms in chronic dialysis patients. Nephrol. Dial. Transplant. 2016, 32, gfw212-1047. [CrossRef]

184. Dantzer, R. Role of the Kynurenine Metabolism Pathway in Inflammation-Induced Depression: Preclinical Approaches. Curr. Top. Behav. Neurosci. 2016, 31, 117-138. [CrossRef]

185. Druzhkova, T.; Pochigaeva, K.; Yakovlev, A.; Kazimirova, E.; Grishkina, M.; Chepelev, A.; Guekht, A.; Gulyaeva, N. Acute stress response to a cognitive task in patients with major depressive disorder: Potential metabolic and proinflammatory biomarkers. Metab. Brain Dis. 2018, 34, 621-629. [CrossRef]

186. Hashimoto, O.; Kuniishi, H.; Nakatake, Y.; Yamada, M.; Wada, K.; Sekiguchi, M. Early life stress from allergic dermatitis causes depressive-like behaviors in adolescent male mice through neuroinflammatory priming. Brain Behav. Immun. 2020, 90, 319-331. [CrossRef] [PubMed]

187. Zhong, H.; Rong, J.; Zhu, C.; Liang, M.; Li, Y.; Zhou, R. Epigenetic Modifications of GABAergic Interneurons Contribute to Deficits in Adult Hippocampus Neurogenesis and Depression-Like Behavior in Prenatally Stressed Mice. Int. J. Neuropsychopharmacol. 2020, 23, 274-285. [CrossRef] [PubMed]

188. Tonon, A.C.; Carissimi, A.; Schimitt, R.L.; De Lima, L.S.; Pereira, F.D.S.; Hidalgo, M.P. How do stress, sleep quality, and chronotype associate with clinically significant depressive symptoms? A study of young male military recruits in compulsory service. Rev. Bras. Psiquiatr. 2020, 42, 54-62. [CrossRef] [PubMed]

189. Schiweck, C.; Claes, S.; Oudenhove, L.V.; Lafit, G.; Vaessen, T.; Beeck, G.O.D.; Berghmans, R.; Wijkhuijs, A.; Muller, N.; Arolt, V. Childhood trauma, suicide risk and inflammatory phenotypes of depression: Insights from monocyte gene expression. Transl. Psychiatry 2020, 10, 296. [CrossRef]

190. Koskinen, M.K.; Mourik, Y.V.; Smit, A.B.; Riga, D.; Spijker, S. From stress to depression: Development of extracellular matrixdependent cognitive impairment following social stress. Sci. Rep. 2020, 10, 17308. [CrossRef] [PubMed]

191. Kautz, M.M.; Coe, C.L.; McArthur, B.A.; Mac Giollabhui, N.; Ellman, L.M.; Abramson, L.Y.; Alloy, L.B. Longitudinal changes of inflammatory biomarkers moderate the relationship between recent stressful life events and prospective symptoms of depression in a diverse sample of urban adolescents. Brain Behav. Immun. 2019, 86, 43-52. [CrossRef] [PubMed]

192. Stroud, C.B.; Vrshek-Shallhorn, S.; Norkett, E.M.; Doane, L. The cortisol awakening response (CAR) interacts with acute interpersonal stress to prospectively predict depressive symptoms among early adolescent girls. Psychoneuroendocrinology 2019, 107, 9-18. [CrossRef]

193. Starr, L.R.; Vrshek-Schallhorn, S.; Stroud, C.B. Serotonergic multilocus genetic variation moderates the association between major interpersonal stress and adolescent depressive symptoms: Replication and candidate environment specification. J. Psychiatr. Res. 2019, 117, 55-61. [CrossRef] [PubMed]

194. Gershon, A.; Hayward, L.; Donenberg, G.R.; Wilson, H. Victimization and traumatic stress: Pathways to depressive symptoms among low-income, African-American girls. Child Abus. Negl. 2018, 86, 223-234. [CrossRef] [PubMed]

195. Cattaneo, A.; Cattane, N.; Malpighi, C.; Czamara, D.; Suarez, A.; Mariani, N.; Kajantie, E.; Luoni, A.; Eriksson, J.G.; Lahti, J.; et al. FoxO1, A2M, and TGF- $\beta 1$ : Three novel genes predicting depression in gene $\mathrm{X}$ environment interactions are identified using cross-species and cross-tissues transcriptomic and miRNomic analyses. Mol. Psychiatry 2018, 23, 2192-2208. [CrossRef]

196. Liu, Y.-Y.; Zhou, X.-Y.; Yang, L.-N.; Wang, H.-Y.; Zhang, Y.-Q.; Pu, J.-C.; Liu, L.-X.; Gui, S.-W.; Zeng, L.; Chen, J.-J.; et al. Social defeat stress causes depression-like behavior with metabolite changes in the prefrontal cortex of rats. PLoS ONE 2017, 12, e0176725. [CrossRef]

197. Patel, D.; Kas, M.J.; Chattarji, S.; Buwalda, B. Rodent models of social stress and neuronal plasticity: Relevance to depressive-like disorders. Behav. Brain Res. 2019, 369, 111900. [CrossRef] [PubMed]

198. Normann, C.; Buttenschøn, H. Gene-environment interactions between HPA-axis genes and stressful life events in depression: A systematic review. Acta Neuropsychiatr. 2019, 31, 186-192. [CrossRef] 
199. Holmes, L., Jr.; Shutman, E.; Chinaka, C.; Deepika, K.; Pelaez, L.; Dabney, K.W. Aberrant Epigenomic Modulation of Glucocorticoid Receptor Gene (NR3C1) in Early Life Stress and Major Depressive Disorder Correlation: Systematic Review and Quantitative Evidence Synthesis. Int. J. Env. Res. Public Health 2019, 16, 4280. [CrossRef]

200. Hei, M.; Chen, P.; Wang, S.; Li, X.; Xu, M.; Zhu, X.; Wang, Y.; Duan, J.; Huang, Y.; Zhao, S. Effects of chronic mild stress induced depression on synaptic plasticity in mouse hippocampus. Behav. Brain Res. 2019, 365, 26-35. [CrossRef] [PubMed]

201. Chen, J.; Wang, Z.-Z.; Zhang, S.; Chu, S.-F.; Mou, Z.; Chen, N.-H. The effects of glucocorticoids on depressive and anxiety-like behaviors, mineralocorticoid receptor-dependent cell proliferation regulates anxiety-like behaviors. Behav. Brain Res. 2019, 362, 288-298. [CrossRef] [PubMed]

202. Agnihotri, S.K.; Sun, L.; Yee, B.K.; Shen, R.; Akundi, R.S.; Zhi, L.; Duncan, M.J.; Cass, W.A.; Büeler, H. PINK1 deficiency is associated with increased deficits of adult hippocampal neurogenesis and lowers the threshold for stress-induced depression in mice. Behav. Brain Res. 2019, 363, 161-172. [CrossRef]

203. Yang, C.; Zhou, C.; Li, J.; Chen, Z.; Shi, H.; Yang, W.; Qin, Y.; Lu, L.; Zhao, L.; Fang, L.; et al. Quantitative proteomic study of the plasma reveals acute phase response and $\mathrm{LXR} / \mathrm{RXR}$ and FXR/RXR activation in the chronic unpredictable mild stress mouse model of depression. Mol. Med. Rep. 2018, 17, 93-102. [CrossRef]

204. Wu, Z.; Wang, G.; Wei, Y.; Xiao, L.; Wang, H. PI3K/AKT/GSK3ß/CRMP-2-mediated neuroplasticity in depression induced by stress. NeuroReport 2018, 29, 1256-1263. [CrossRef]

205. Quinn, M.E.; Grant, K.E.; Adam, E.K. Negative cognitive style and cortisol recovery accentuate the relationship between life stress and depressive symptoms. Stress 2017, 21, 119-127. [CrossRef]

206. Huang, P.; Gao, T.; Dong, Z.; Zhou, C.; Lai, Y.; Pan, T.; Liu, Y.; Zhao, X.; Sun, X.; Hua, H.; et al. Neural circuitry among connecting the hippocampus, prefrontal cortex and basolateral amygdala in a mouse depression model: Associations correlations between BDNF levels and BOLD-fMRI signals. Brain Res. Bull. 2019, 153, 350. [CrossRef] [PubMed]

207. Bondar, N.; Bryzgalov, L.; Ershov, N.; Gusev, F.; Reshetnikov, V.; Avgustinovich, D.; Tenditnik, M.; Rogaev, E.; Merkulova, T. Molecular Adaptations to Social Defeat Stress and Induced Depression in Mice. Mol. Neurobiol. 2017, 55, 3394-3407. [CrossRef]

208. Arcego, D.M.; Toniazzo, A.P.; Krolow, R.; Lampert, C.; Berlitz, C.; Garcia, E.D.S.; Nicola, F.D.C.; Hoppe, J.B.; Gaelzer, M.M.; Klein, C.P.; et al. Impact of High-Fat Diet and Early Stress on Depressive-Like Behavior and Hippocampal Plasticity in Adult Male Rats. Mol. Neurobiol. 2017, 55, 2740-2753. [CrossRef]

209. Knyazev, G.G.; Bazovkina, D.V.; Savostyanov, A.N.; Naumenko, V.S.; Kuznetsova, V.B.; Proshina, E.A. Suppression mediates the effect of 5-HTTLPR by stress interaction on depression. Scand. J. Psychol. 2017, 58, 373-378. [CrossRef]

210. Connolly, S.L.; Alloy, L.B. Rumination interacts with life stress to predict depressive symptoms: An ecological momentary assessment study. Behav. Res. Ther. 2017, 97, 86-95. [CrossRef]

211. Chen, Y.; Peng, Y.; Ma, X.; Dong, X. Conscientiousness Moderates the Relationship Between Perceived Stress and Depressive Symptoms Among U.S. Chinese Older Adults. J. Gerontol. Ser. A Boil. Sci. Med Sci. 2017, 72, S108-S112. [CrossRef]

212. Boku, S.; Nakagawa, S.; Toda, H.; Hishimoto, A. Neural basis of major depressive disorder: Beyond monoamine hypothesis. Psychiatry Clin. Neurosci. 2017, 72, 3-12. [CrossRef]

213. Dean, J.; Keshavan, M. The neurobiology of depression: An integrated view. Asian J. Psychiatry 2017, 27, 101-111. [CrossRef] [PubMed]

214. Jeon, S.W.; Kim, Y.-K. Inflammation-induced depression: Its pathophysiology and therapeutic implications. J. Neuroimmunol. 2017, 313, 92-98. [CrossRef]

215. Savitz, J. Role of Kynurenine Metabolism Pathway Activation in Major Depressive Disorders. Curr. Top Behav. Neurosci. 2016, 31, 249-267. [CrossRef]

216. Serafini, G.; Adavastro, G.; Canepa, G.; Capobianco, L.; Conigliaro, C.; Pittaluga, F.; Murri, M.B.; Valchera, A.; De Berardis, D.; Pompili, M.; et al. Abnormalities in Kynurenine Pathway Metabolism in Treatment-Resistant Depression and Suicidality: A Systematic Review. CNS Neurol. Disord. Drug Targets 2017, 16, 440-453. [CrossRef]

217. Duan, K.-M.; Ma, J.-H.; Wang, S.-Y.; Huang, Z.; Zhou, Y.; Yu, H. The role of tryptophan metabolism in postpartum depression. Metab. Brain Dis. 2018, 33, 647-660. [CrossRef]

218. Wang, B.; Lian, Y.; Su, W.-J.; Liu, L.; Li, J.; Jiang, C.; Wang, Y. Fr-HMGB1 and ds-HMGB1 activate the kynurenine pathway via different mechanisms in association with depressive-like behavior. Mol. Med. Rep. 2019, 20, 359-367. [CrossRef]

219. Kruse, J.L.; Cho, J.H.-J.; Olmstead, R.; Hwang, L.; Faull, K.; Eisenberger, N.I.; Irwin, M.R. Kynurenine metabolism and inflammation-induced depressed mood: A human experimental study. Psychoneuroendocrinology 2019, 109, 104371. [CrossRef]

220. Kubacka, J.; Stefańska, A.; Sypniewska, G. Kynurenine pathway: The link between depressive disorders and inflammation. Postepy Hig. Med. Dosw. 2020, 74, 331-339. [CrossRef]

221. Liu, H.; Ding, L.; Zhang, H.; Mellor, D.; Wu, H.; Zhao, D.; Wu, C.; Lin, Z.; Yuan, J.; Peng, D. The Metabolic Factor Kynurenic Acid of Kynurenine Pathway Predicts Major Depressive Disorder. Front. Psychiatry 2018, 9, 552. [CrossRef] [PubMed]

222. Halahakoon, D.C.; Lewis, G.; Roiser, J.P. Cognitive Impairment and Depression-Cause, Consequence, or Coincidence? JAMA Psychiatry 2019, 76, 239-240. [CrossRef] [PubMed]

223. Zlatar, Z.Z.; Muniz, M.; Galasko, D.; Salmon, D.P. Subjective Cognitive Decline Correlates with Depression Symptoms and Not with Concurrent Objective Cognition in a Clinic-Based Sample of Older Adults. J. Gerontol. Ser. B 2017, 73, 1198-1202. [CrossRef] [PubMed] 
224. Noda, Y.; Zomorrodi, R.; Vila-Rodriguez, F.; Downar, J.; Farzan, F.; Cash, R.F.; Rajji, T.K.; Daskalakis, Z.J.; Blumberger, D.M. Impaired neuroplasticity in the prefrontal cortex in depression indexed through paired associative stimulation. Depress. Anxiety 2018, 35, 448-456. [CrossRef] [PubMed]

225. Krzak, A.M.; Cao, J.J.L.; Agius, M.; Hoschl, C. Does neurogenesis relate to depression and do antidepressants affect neurogenesis? Psychiatr Danub. 2017, 29 (Suppl. S3), 241-246. [PubMed]

226. Vermeer, J.; Rice, D.; McIntyre, A.; Viana, R.; Macaluso, S.; Teasell, R. Correlates of depressive symptoms in individuals attending outpatient stroke clinics. Disabil. Rehabil. 2016, 39, 43-49. [CrossRef]

227. Christensen, G.T.; Rozing, M.P.; Mortensen, E.L.; Christensen, K.; Osler, M. Young adult cognitive ability and subsequent major depression in a cohort of 666,804 Danish men. J. Affect. Disord. 2018, 235, 162-167. [CrossRef]

228. Hankin, B.L.; Young, J.F.; Gallop, R.; Garber, J. Cognitive and Interpersonal Vulnerabilities to Adolescent Depression: Classification of Risk Profiles for a Personalized Prevention Approach. J. Abnorm. Child Psychol. 2018, 46, 1521-1533. [CrossRef]

229. Arnetz, B.B.; Sudan, S.; Arnetz, J.E.; Yamin, J.B.; Lumley, M.A.; Beck, J.S.; Stemmer, P.M.; Burghardt, P.; Counts, S.E.; Jamil, H. Dysfunctional neuroplasticity in newly arrived Middle Eastern refugees in the U.S.: Association with environmental exposures and mental health symptoms. PLoS ONE 2020, 15, e0230030. [CrossRef] [PubMed]

230. Yamanishi, K.; Doe, N.; Mukai, K.; Ikubo, K.; Hashimoto, T.; Uwa, N.; Sumida, M.; El-Darawish, Y.; Gamachi, N.; Li, W.; et al. Interleukin-18-deficient mice develop hippocampal abnormalities related to possible depressive-like behaviors. Neuroscience 2019, 408, 147-160. [CrossRef]

231. Nissen, L.R.; Karstoft, K.-I.; Vedtofte, M.S.; Nielsen, A.B.S.; Osler, M.; Mortensen, E.L.; Christensen, G.T.; Andersen, S.B. Low-level cognitive ability in young adulthood and other risk factors of depression in an observational cohort study among deployed Danish soldiers. Soc. Psychiatry Psychiatr. Epidemiol. 2019, 54, 497-506. [CrossRef]

232. Liu, R.T.; McArthur, B.A.; Burke, T.A.; Hamilton, J.L.; Mac Giollabhui, N.; Stange, J.P.; Hamlat, E.J.; Abramson, L.Y.; Alloy, L.B. A Latent Structure Analysis of Cognitive Vulnerability to Depression in Adolescence. Behav. Ther. 2018, 50, 755-764. [CrossRef]

233. Bernstein, E.E.; Kleiman, E.M.; Van Bork, R.; Moriarity, D.P.; Mac Giollabhui, N.; McNally, R.J.; Abramson, L.Y.; Alloy, L.B. Unique and predictive relationships between components of cognitive vulnerability and symptoms of depression. Depress. Anxiety 2019, 36, 950-959. [CrossRef] [PubMed]

234. Prussien, K.V.; DeBaun, M.R.; Yarboi, J.; Bemis, H.; McNally, C.; Williams, E.; Compas, B.E. Cognitive Function, Coping, and Depressive Symptoms in Children and Adolescents with Sickle Cell Disease. J. Pediatr. Psychol. 2017, 43, 543-551. [CrossRef]

235. Porras-Segovia, A.; Valmisa, E.; Gutiérrez, B.; Ruiz, I.; Rodríguez-Barranco, M.; Cervilla, J. Prevalence and correlates of major depression in Granada, Spain: Results from the Granad $\Sigma$ p study. Int. J. Soc. Psychiatry 2018, 64, 450-458. [CrossRef] [PubMed]

236. Yang, B.; Yu, H.; Xing, M.; He, R.; Liang, R.; Zhou, L. The relationship between cognition and depressive symptoms, and factors modifying this association, in Alzheimer's disease: A multivariate multilevel model. Arch. Gerontol. Geriatr. 2017, $72,25-31$. [CrossRef]

237. Liu, W.; Ge, T.; Leng, Y.; Pan, Z.; Fan, J.; Yang, W.; Cui, R. The Role of Neural Plasticity in Depression: From Hippocampus to Prefrontal Cortex. Neural Plast. 2017, 2017, 6871089. [CrossRef]

238. Kraus, C.; Castren, E.; Kasper, S.; Lanzenberger, R. Serotonin and neuroplasticity-Links between molecular, functional and structural pathophysiology in depression. Neurosci. Biobehav. Rev. 2017, 77, 317-326. [CrossRef] [PubMed]

239. Kim, B.J.; Nakaoka, S.; Underwood, C. The Impacts of Social Support and Cognitive Function on Depression among CommunityDwelling Older Japanese Americans. Soc. Work. Public Health 2016, 32, 82-93. [CrossRef]

240. MacKenzie, L.E.; Uher, R.; Pavlova, B. Cognitive Performance in First-Degree Relatives of Individuals With vs Without Major Depressive Disorder: A Meta-analysis. JAMA Psychiatry 2019, 76, 297-305. [CrossRef]

241. Roiser, J.P.; Elliott, R.; Sahakian, B. Cognitive Mechanisms of Treatment in Depression. Neuropsychopharmacology 2011, 37, 117-136. [CrossRef]

242. Sunley, A.K.; Lok, A.; White, M.; Snijder, M.B.; van Zuiden, M.; Zantvoord, J.B.; Derks, E.M. Ethnic and sex differences in the association of child maltreatment and depressed mood. The HELIUS study. Child Abus. Negl. 2019, 99, 104239. [CrossRef]

243. Moustafa, A.A.; Crouse, J.J.; Herzallah, M.M.; Salama, M.; Mohamed, W.; Misiak, B.; Frydecka, D.; Al-Dosari, N.F.; Megreya, A.M.; Mattock, K. Depression Following Major Life Transitions in Women: A Review and Theory. Psychol. Rep. 2019, 123, 1501-1517. [CrossRef]

244. Kobezak, H.M.; Gibb, B.E. Prospective associations between social anxiety and depression in youth: The moderating role of maternal major depressive disorder. J. Adolesc. 2020, 82, 19-22. [CrossRef]

245. Dadi, A.F.; Mwanri, L.; Woodman, R.; Azale, T.; Miller, E. Causal mechanisms of postnatal depression among women in Gondar town, Ethiopia: Application of a stress-process model with generalized structural equation modeling. Reprod. Health 2020, 17, 63. [CrossRef]

246. Wang, Z.; Shi, Y.; Liu, F.; Jia, N.; Gao, J.; Pang, X.; Deng, F. Diversiform Etiologies for Post-stroke Depression. Front. Psychiatry 2019, 9, 761. [CrossRef]

247. Volz, M.; Voelkle, M.C.; Werheid, K. General self-efficacy as a driving factor of post-stroke depression: A longitudinal study. Neuropsychol. Rehabil. 2018, 29, 1426-1438. [CrossRef]

248. Byrne, E.M.; Timmerman, A.; Wray, N.R.; Agerbo, E. Sleep Disorders and Risk of Incident Depression: A Population Case-Control Study. Twin Research \& Human Genetics. Off. J. Int. Soc. Twin Stud. 2019, 22, 140-146. 
249. Albrecht, J.S.; Barbour, L.; Abariga, S.A.; Rao, V.; Perfetto, E.M. Risk of Depression after Traumatic Brain Injury in a Large National Sample. J. Neurotrauma 2019, 36, 300-307. [CrossRef]

250. Kalmbach, D.A.; Pillai, V.; Drake, C.L. Nocturnal insomnia symptoms and stress-induced cognitive intrusions in risk for depression: A 2-year prospective study. PLOS ONE 2018, 13, e0192088. [CrossRef]

251. Hamano, T.; Li, X.; Lonn, S.L.; Nabika, T.; Sundquist, J.; Sundquist, K. Is familial risk for depression confounded by individual and familial socioeconomic factors and neighborhood environmental factors? A 7-year follow-up study in Sweden. Psychiatry Res. 2018, 266, 30-35. [CrossRef]

252. Guintivano, J.; Manuck, T.; Meltzer-Brody, S. Predictors of Postpartum Depression: A Comprehensive Review of the Last Decade of Evidence. Clin. Obstet. Gynecol. 2018, 61, 591-603. [CrossRef]

253. Gayman, M.D.; Kail, B.; Spring, A.; Greenidge, G.R. Risk and Protective Factors for Depressive Symptoms Among African American Men: An Application of the Stress Process Model. J. Gerontol. Ser. B 2017, 73, 219-229. [CrossRef]

254. Markkula, N.; Marola, N.; Nieminen, T.; Koskinen, S.; Saarni, S.I.; Härkänen, T.; Suvisaari, J. Predictors of new-onset depressive disorders-Results from the longitudinal Finnish Health 2011 Study. J. Affect. Disord. 2017, 208, 255-264. [CrossRef]

255. Koukounari, A.; Stringaris, A.; Maughan, B. Pathways from maternal depression to young adult offspring depression: An exploratory longitudinal mediation analysis. Int. J. Methods Psychiatr. Res. 2017, 26, e1520. [CrossRef]

256. Cernadas, J.M.C. Postpartum depression: Risks and early detection. Arch. Argent. Pediatr. 2020, 118, 154-155. [CrossRef]

257. Pullmer, R.; Zaitsoff, S.L.; Coelho, J.S. Cognitive and behavioral correlates of depressive symptoms in a community sample of adolescents. Clin. Child Psychol. Psychiatry 2019, 25, 98-105. [CrossRef]

258. Ward, A.R.; Sibley, M.H.; Musser, E.D.; Campez, M.; Bubnik-Harrison, M.G.; Meinzer, M.C.; Yeguez, C. Relational impairments, sluggish cognitive tempo, and severe inattention are associated with elevated self-rated depressive symptoms in adolescents with ADHD. ADHD Atten. Deficit Hyperact. Disord. 2019, 11, 289-298. [CrossRef]

259. Trick, L.; Watkins, E.R.; Henley, W.; Gandhi, M.M.; Dickens, C. Perseverative negative thinking predicts depression in people with acute coronary syndrome. Gen. Hosp. Psychiatry 2019, 61, 16-25. [CrossRef]

260. Speed, D.; Hemani, G.; Speed, M.S.; Børglum, A.; Østergaard, S.D.; Major Depressive Disorder Working Group of the Psychiatric Genomics Consortium. Investigating the causal relationship between neuroticism and depression via Mendelian randomization. Acta Psychiatr. Scand. 2019, 139, 395-397. [CrossRef]

261. Orchard, F.; Pass, L.; Reynolds, S. 'I Am Worthless and Kind'; the specificity of positive and negative self-evaluation in adolescent depression. Br. J. Clin. Psychol. 2019, 58, 260-273. [CrossRef]

262. Nankoo, M.M.A.; Palermo, R.; Bell, J.; Pestell, C. Examining the Rate of Self-Reported ADHD-Related Traits and Endorsement of Depression, Anxiety, Stress, and Autistic-Like Traits in Australian University Students. J. Atten. Disord. 2018, 23, 869-886. [CrossRef]

263. Konsztowicz, S.; Lepage, M. The role of illness engulfment in the association between insight and depressive symptomatology in schizophrenia. J. Psychiatr. Res. 2019, 111, 1-7. [CrossRef]

264. Fossati, P. Circuit based anti-correlation, attention orienting, and major depression. CNS Spectr. 2019, 24, 94-101. [CrossRef]

265. DeJong, H.; Fox, E.; Stein, A. Does rumination mediate the relationship between attentional control and symptoms of depression? J. Behav. Exp. Psychiatry 2019, 63, 28-35. [CrossRef]

266. Carvalho, S.A.; Trindade, I.A.; Gillanders, D.; Pinto-Gouveia, J.; Castilho, P. Cognitive fusion and depressive symptoms in women with chronic pain: A longitudinal growth curve modelling study over 12 months. Clin. Psychol. Psychother. 2019, 26, 616-625. [CrossRef]

267. Blöte, A.W.; Westenberg, P.M. The temporal association between emotional clarity and depression symptoms in adolescents. J. Adolesc. 2019, 71, 110-118. [CrossRef]

268. Bailen, N.H.; Wu, H.; Thompson, R.J. Meta-emotions in daily life: Associations with emotional awareness and depression. Emotion 2019, 19, 776-787. [CrossRef] [PubMed]

269. Zamora-Racaza, G.; Azizoddin, D.R.; Ishimori, M.L.; Ormseth, S.R.; Wallace, D.J.; Penserga, E.G.; Sumner, L.; Ayeroff, J.; Draper, T.; Nicassio, P.M.; et al. Role of psychosocial reserve capacity in anxiety and depression in patients with systemic lupus erythematosus. Int. J. Rheum. Dis. 2017, 21, 850-858. [CrossRef]

270. Trindade, I.A.; Marta-Simoes, J.; Ferreira, C.; Pinto-Gouveia, J. Chronic illness-related cognitive fusion explains the impact of body dissatisfaction and shame on depression symptoms in breast cancer patients. Clin. Psychol. Psychother. 2018, 25, 886-893. [CrossRef]

271. Smith, E.M.; Reynolds, S.; Orchard, F.; Whalley, H.C.; Chan, S.W. Cognitive biases predict symptoms of depression, anxiety and wellbeing above and beyond neuroticism in adolescence. J. Affect. Disord. 2018, 241, 446-453. [CrossRef] [PubMed]

272. Senra, C.; Merino, H.; Ferreiro, F. Exploring the link between perfectionism and depressive symptoms: Contribution of rumination and defense styles. J. Clin. Psychol. 2017, 74, 1053-1066. [CrossRef] [PubMed]

273. Otani, K.; Suzuki, A.; Matsumoto, Y.; Shirata, T. Interrelations among negative core beliefs, attachment anxiety and low selfdirectedness, putative central constructs of depression vulnerabilities in cognitive, attachment and psychobiological personality theories. Psychiatry Res. 2018, 268, 34-36. [CrossRef] [PubMed]

274. Orchard, F.; Reynolds, S. The combined influence of cognitions in adolescent depression: Biases of interpretation, self-evaluation, and memory. Br. J. Clin. Psychol. 2018, 57, 420-435. [CrossRef] 
275. Mac Giollabhui, N.; Hamilton, J.L.; Nielsen, J.; Connolly, S.L.; Stange, J.P.; Varga, S.; Burdette, E.; Olino, T.M.; Abramson, L.Y.; Alloy, L.B. Negative cognitive style interacts with negative life events to predict first onset of a major depressive episode in adolescence via hopelessness. J. Abnorm. Psychol. 2018, 127, 1-11. [CrossRef]

276. Kube, T.; Siebers, V.H.A.; Herzog, P.; Glombiewski, J.A.; Doering, B.K.; Rief, W. Integrating situation-specific dysfunctional expectations and dispositional optimism into the cognitive model of depression-A path-analytic approach. J. Affect. Disord. 2018, 229, 199-205. [CrossRef] [PubMed]

277. Kube, T.; Glombiewski, J.A.; Rief, W. Situational expectations mediate the effect of global beliefs on depressive symptoms: A 1-year prospective study using a student sample. Curr. Opin. Psychiatry 2018, 31, 409-416. [CrossRef] [PubMed]

278. Denis, A.; Luminet, O. Cognitive factors and post-partum depression: What is the influence of general personality traits, rumination, maternal self-esteem, and alexithymia? Clin. Psychol. Psychother. 2017, 25, 359-367. [CrossRef]

279. Burke, T.A.; McArthur, B.A.; Daryanani, I.; Abramson, L.Y.; Alloy, L.B. Latent classes of trait affect and cognitive affective regulation strategies are associated with depression, non-suicidal self-injury, and well-being. J. Affect. Disord. 2017, 225, 180-187. [CrossRef] [PubMed]

280. Zhou, L.; Chen, J. Life events and hopelessness depression: The influence of affective experience. PLoS ONE 2017, 12, e0187898. [CrossRef]

281. Rudolph, K.D.; Davis, M.M.; Monti, J.D. Cognition-emotion interaction as a predictor of adolescent depressive symptoms. Dev. Psychol. 2017, 53, 2377-2383. [CrossRef] [PubMed]

282. Platt, B.; Waters, A.M.; Schulte-Koerne, G.; Engelmann, L.; Salemink, E. A review of cognitive biases in youth depression: Attention, interpretation and memory. Cogn. Emot. 2016, 31, 462-483. [CrossRef]

283. Normansell, K.M.; Wisco, B.E. Negative interpretation bias as a mechanism of the relationship between rejection sensitivity and depressive symptoms. Cogn. Emot. 2016, 31, 950-962. [CrossRef]

284. Macrynikola, N.; Goklani, S.; Slotnick, J.; Miranda, R. Positive future-oriented fantasies and depressive symptoms: Indirect relationship through brooding. Conscious. Cogn. 2017, 51, 1-9. [CrossRef] [PubMed]

285. Fuhr, K.; Reitenbach, I.; Kraemer, J.; Hautzinger, M.; Meyer, T.D. Attachment, dysfunctional attitudes, self-esteem, and association to depressive symptoms in patients with mood disorders. J. Affect. Disord. 2017, 212, 110-116. [CrossRef] [PubMed]

286. Everaert, J.; Grahek, I.; Koster, E. Individual differences in cognitive control over emotional material modulate cognitive biases linked to depressive symptoms. Cogn. Emot. 2016, 31, 736-746. [CrossRef]

287. Everaert, J.; Grahek, I.; Duyck, W.; Buelens, J.; Bergh, N.V.D.; Koster, E.H.W. Mapping the interplay among cognitive biases, emotion regulation, and depressive symptoms. Cogn. Emot. 2016, 31, 726-735. [CrossRef]

288. Caputi, M.; Pantaleo, G.; Scaini, S. Do Feelings of Loneliness Mediate the Relationship between Sociocognitive Understanding and Depressive Symptoms During Late Childhood and Early Adolescence? J. Genet Psychol. 2017, 178, 207-216. [CrossRef] [PubMed]

289. Powell, V.; Riglin, L.; Hammerton, G.; Eyre, O.; Martin, J.; Anney, R.; Thapar, A.; Rice, F. What explains the link between childhood ADHD and adolescent depression? Investigating the role of peer relationships and academic attainment. Eur. Child Adolesc. Psychiatry 2020, 29, 1581-1591. [CrossRef]

290. Fang, L.; Marchetti, I.; Hoorelbeke, K.; Koster, E.H. Do daily dynamics in rumination and affect predict depressive symptoms and trait rumination? An experience sampling study. J. Behav. Ther. Exp. Psychiatry 2018, 63, 66-72. [CrossRef]

291. Marmot, M.; Allen, J.; Boyce, T.; Goldblatt, P.; Morrison, J. Health Equity in England: The Marmot Review 10 Years On, in The Health Foundation; Institute of Health Equity: London, UK, 2020.

292. Mutyambizi, C.; Booysen, F.; Stornes, P.; Eikemo, T.A. Subjective social status and inequalities in depressive symptoms: A gender-specific decomposition analysis for South Africa. Int. J. Equity Health 2019, 18, 87. [CrossRef]

293. Lu, N.; Peng, C. Community-based structural social capital and depressive symptoms of older urban Chinese adults: The mediating role of cognitive social capital. Arch. Gerontol. Geriatr. 2019, 82, 74-80. [CrossRef]

294. Khaled, S.M. Prevalence and potential determinants of subthreshold and major depression in the general population of Qatar. J. Affect. Disord. 2019, 252, 382-393. [CrossRef]

295. McCormick, N.; Trupin, L.; Yelin, E.H.; Katz, P.P. Socioeconomic Predictors of Incident Depression in Systemic Lupus Erythematosus. Arthritis Rheum. 2017, 70, 104-113. [CrossRef]

296. Brown, C.R.; The U.S. Caribbean Alliance for Health Disparities Research Group (USCAHDR); Hambleton, I.R.; Sobers-Grannum, N.; Hercules, S.M.; Unwin, N.; Harris, E.N.; Wilks, R.; MacLeish, M.; Sullivan, L.; et al. Social determinants of depression and suicidal behaviour in the Caribbean: A systematic review. BMC Public Health 2017, 17, 577. [CrossRef]

297. De Oliveira, G.; Cianelli, R.; Gattamorta, K.; Kowalski, N.; Peragallo, N. Social Determinants of Depression Among Hispanic Women. J. Am. Psychiatr. Nurses Assoc. 2016, 23, 28-36. [CrossRef] [PubMed]

298. Strachan, E.; Duncan, G.; Horn, E.; Turkheimer, E. Neighborhood deprivation and depression in adult twins: Genetics and gene $\times$ environment interaction. Psychol. Med. 2016, 47, 627-638. [CrossRef]

299. Backhouse, E.V.; McHutchison, C.A.; Cvoro, V.; Shenkin, S.D.; Wardlaw, J.M. Cognitive ability, education and socioeconomic status in childhood and risk of post-stroke depression in later life: A systematic review and meta-analysis. PLoS ONE 2018, 13, e0200525. [CrossRef]

300. Winding, T.N.; Skouenborg, L.A.; Mortensen, V.L.; Andersen, J.H. Is bullying in adolescence associated with the development of depressive symptoms in adulthood?: A longitudinal cohort study. BMC Psychol. 2020, 8, 122. [CrossRef] 
301. Sparling, T.M.; Waid, J.L.; Wendt, A.S.; Gabrysch, S. Depression among women of reproductive age in rural Bangladesh is linked to food security, diets and nutrition. Public Health Nutr. 2020, 23, 660-673. [CrossRef] [PubMed]

302. Tomita, A.; Cuadros, D.F.; Mabhaudhi, T.; Sartorius, B.; Ncama, B.P.; Dangour, A.D.; Tanser, F.; Modi, A.T.; Slotow, R.; Burns, J.K. Spatial clustering of food insecurity and its association with depression: A geospatial analysis of nationally representative South African data, 2008-2015. Sci. Rep. 2020, 10, 13771. [CrossRef] [PubMed]

303. Millender, E.; Barile, J.P.; Bagneris, J.R.; Harris, R.M.; De Faria, L.; Wong, F.Y.; Crusto, C.A.; Taylor, J.Y. Associations between social determinants of health, perceived discrimination, and body mass index on symptoms of depression among young African American mothers. Arch. Psychiatr. Nurs. 2020, 35, 94-101. [CrossRef]

304. Li, E.T.; Carracher, E.; Bird, T. Linking childhood emotional abuse and adult depressive symptoms: The role of mentalizing incapacity. Child Abus. Negl. 2019, 99, 104253. [CrossRef]

305. Leonard, K.S.; Evans, M.B.; Kjerulff, K.H.; Downs, D.S. Postpartum Perceived Stress Explains the Association between Perceived Social Support and Depressive Symptoms. Women's Health Issues 2020, 30, 231-239. [CrossRef]

306. Lee, Y.; Hung, C.-F.; Chien, C.-Y.; Lin, P.-Y.; Lin, M.-C.; Wang, C.-C.; Lu, H.-I.; Chen, Y.-C.; Chong, M.-Y.; Wang, L.-J. Comparison of prevalence and associated factors of depressive disorder between patients with head and neck cancer and those with lung cancer at a tertiary hospital in Taiwan: A cross-sectional study. BMJ Open 2020, 10, e037918. [CrossRef]

307. Koga, C.; Tsuji, T.; Hanazato, M.; Suzuki, N.; Kondo, K. Elder Abuse and Depressive Symptoms: Which is Cause and Effect? Bidirectional Longitudinal Studies From the JAGES. J. Interpers. Violence 2020, 1-17. [CrossRef]

308. Kim, B.; Park, E.Y. The combined effect of socioeconomic status and metabolic syndrome on depression: The Korean National Health and Nutrition Examination Survey (KNHANES). BMC Public Health 2020, 20, 617. [CrossRef]

309. Karl, M.; Schaber, R.; Kress, V.; Kopp, M.; Martini, J.; Weidner, K.; Garthus-Niegel, S. Precarious working conditions and psychosocial work stress act as a risk factor for symptoms of postpartum depression during maternity leave: Results from a longitudinal cohort study. BMC Public Health 2020, 20, 1505. [CrossRef]

310. Flouri, E.; Francesconi, M.; Midouhas, E.; Lewis, G. Prenatal and childhood adverse life events, inflammation and depressive symptoms across adolescence. J. Affect. Disord. 2019, 260, 577-582. [CrossRef] [PubMed]

311. Dong, X.; Zhao, L.; Sun, T.; Yun, F.; Qiu, L. Prevalence of Depressive Symptoms and Associated Factors among Internal Migrants with Tuberculosis: A Cross-Sectional Study in China. Am. J. Trop. Med. Hyg. 2020, 102, 31-35. [CrossRef]

312. Czaderny, K. Risk factors for depression. New evidence on selenium deficiency and depressive disorders. Psychiatr. Polska 2020, 54, 1109-1121. [CrossRef]

313. Cavazos-Rehg, P.; Xu, C.; Kasson, E.; Byansi, W.; Bahar, O.S.; Ssewamala, F. Social and Economic Equity and Family Cohesion as Potential Protective Factors from Depression Among Adolescents Living with HIV in Uganda. AIDS Behav. 2020, 24, $2546-2554$. [CrossRef]

314. Benjet, C.; Axinn, W.G.; Hermosilla, S.; Schulz, P.; Cole, F.; Sampson, L.; Ghimire, D. Exposure to Armed Conflict in Childhood vs Older Ages and Subsequent Onset of Major Depressive Disorder. JAMA Netw. Open 2020, 3, e2019848. [CrossRef]

315. Ayano, G.; Tsegay, L.; Solomon, M. Food insecurity and the risk of depression in people living with HIV/AIDS: A systematic review and meta-analysis. AIDS Res. Ther. 2020, 17, 1-11. [CrossRef]

316. Wang, M.; Zheng, X.; Xia, G.; Liu, D.; Chen, P.; Zhang, W. Association between negative life events and early adolescents' depression: The moderating effects of catechol-O-methyltransferase (COMT) gene val158met polymorphism and parenting behavior. Acta Psychol. Sin. 2019, 51, 903-913.

317. Ren, Z.; Zhou, G.; Wang, Q.; Xiong, W.; Ma, J.; He, M.; Shen, Y.; Fang, X.; Guo, X.; Gong, P. Associations of family relationships and negative life events with depressive symptoms among Chinese adolescents: A cross-sectional study. PLoS ONE 2019, 14, e0219939. [CrossRef]

318. McQuaid, R.J.; Gabrys, R.L.; McInnis, O.A.; Anisman, H.; Matheson, K. Understanding the Relation Between Early-Life Adversity and Depression Symptoms: The Moderating Role of Sex and an Interleukin-1ß Gene Variant. Front. Psychiatry 2019, 10, 151. [CrossRef]

319. Liu, W.J.; Zhou, L.; Wang, X.Q.; Yang, B.X.; Wang, Y.; Jiang, J.F. Mediating role of resilience in relationship between negative life events and depression among Chinese adolescents. Arch. Psychiatr. Nurs. 2019, 33, 116-122. [CrossRef] [PubMed]

320. Lee, Y.S.; Kim, T.H. Household food insecurity and breakfast skipping: Their association with depressive symptoms. Psychiatry Res. 2018, 271, 83-88. [CrossRef]

321. Kim, S.; Subramanian, S.V. Income Volatility and Depressive Symptoms among Elderly Koreans. Int. J. Environ. Res. Public Health 2019, 16, 25. [CrossRef]

322. Hessel, P.; Botero, M.A.M.; Cuartas, J. Acute exposure to violent neighborhood crime and depressive symptoms among older individuals in Colombia. Health Place 2019, 59, 102162. [CrossRef]

323. Gao, X.; Leng, Y.; Guo, Y.; Yang, J.; Cui, Q.; Geng, B.; Hu, H.; Zhou, Y. Association between earthquake experience and depression 37 years after the Tangshan earthquake: A cross-sectional study. BMJ Open 2019, 9, e026110. [CrossRef]

324. Friberg, A.S.; Moustsen, I.R.; Larsen, S.B.; Hartung, T.; Andersen, E.W.; Olsen, M.H.; Tjonneland, A.; Kjaer, S.K.; Johansen, C.; Brasso, K.; et al. Educational level and the risk of depression after prostate cancer. Acta Oncol. 2019, 58, 722-729. [CrossRef]

325. Easton, S.D.; Kong, J.; Gregas, M.C.; Shen, C.; Shafer, K. Child Sexual Abuse and Depression in Late Life for Men: A PopulationBased, Longitudinal Analysis. J. Gerontol. Ser. B 2017, 74, 842-852. [CrossRef] 
326. Eduardo, J.A.F.D.P.; de Rezende, M.G.; Menezes, P.; Del-Ben, C.M. Preterm birth as a risk factor for postpartum depression: A systematic review and meta-analysis. J. Affect. Disord. 2019, 259, 392-403. [CrossRef]

327. Filho, B.F.D.L.; Dias, V.D.N.; Carlos, A.G.; Fontes, F.P.; De Sousa, A.G.P.; Gazzola, J.M. Factors related to depressive symptoms in older adult patients with type 2 Diabetes Mellitus. Exp. Gerontol. 2018, 117, 72-75. [CrossRef] [PubMed]

328. Carpena, M.X.; Dumith, S.C.; De Mola, C.L.; Neiva-Silva, L. Sociodemographic, behavioral, and health-related risk factors for depression among men and women in a southern Brazilian city. Rev. Bras. Psiquiatr. 2019, 41, 396-402. [CrossRef]

329. Bonful, H.A.; Anum, A. Sociodemographic correlates of depressive symptoms: A cross-sectional analytic study among healthy urban Ghanaian women. BMC Public Health 2019, 19, 50. [CrossRef]

330. Boing, L.; Pereira, G.S.; Araújo, C.D.C.R.D.; Sperandio, F.F.; Loch, M.D.S.G.; Bergmann, A.; Borgatto, A.F.; Guimarães, A.C.D.A. Factors associated with depression symptoms in women after breast cancer. Revista De Saude Publica 2019, 53, 30. [CrossRef]

331. Azizi, M.; Fooladi, E.; Bell, R.J.; Elyasi, F.; Masoumi, M.; Davis, S.R. Depressive symptoms and associated factors among Iranian women at midlife: A community-based, cross-sectional study. Menopause 2019, 26, 1125-1132. [CrossRef]

332. Zhang, C.; Barnett, A.; Sit, C.H.P.; Lai, P.; Johnston, J.M.; Lee, R.S.Y.; Cerin, E. Cross-sectional associations of objectively assessed neighbourhood attributes with depressive symptoms in older adults of an ultra-dense urban environment: The Hong Kong ALECS study. BMJ Open 2018, 8, e020480. [CrossRef] [PubMed]

333. Yamamoto, M. Perceived Neighborhood Conditions and Depression: Positive Local News as a Buffering Factor. Health Commun. 2016, 33, 156-163. [CrossRef]

334. Wu, Q.; Chi, P.; Lin, X.; Du, H. Child maltreatment and adult depressive symptoms: Roles of self-compassion and gratitude. Child Abus. Negl. 2018, 80, 62-69. [CrossRef]

335. Park, D.-J.; Kang, J.-H.; Lee, K.-E.; Kang, S.W.; Kwok, S.-K.; Kim, S.-K.; Choe, J.-Y.; Kim, H.-A.; Sung, Y.-K.; Shin, K.; et al. Association of depression with socioeconomic status, anticardiolipin antibodies, and organ damage in patients with systemic lupus erythematosus: Results from the KORNET registry. Clin. Exp. Rheumatol. 2018, 36, 627-635.

336. Mahenge, B.; Stöckl, H.; Mizinduko, M.; Mazalale, J.; Jahn, A. Adverse childhood experiences and intimate partner violence during pregnancy and their association to postpartum depression. J. Affect. Disord. 2018, 229, 159-163. [CrossRef]

337. Lahav-Kadmiel, Z.; Brunstein-Klomek, A. Bullying victimization and depressive symptoms in adolescence: The moderating role of parent-child conflicts among boys and girls. J. Adolesc. 2018, 68, 152-158. [CrossRef]

338. Flores, R.J.; Campo-Arias, A.; Stimpson, J.; Chalela, C.; Reyes-Ortiz, C.A. The Association Between Past Sexual Abuse and Depression in Older Adults from Colombia. J. Geriatr. Psychiatry Neurol. 2017, 31, 13-18. [CrossRef]

339. Ayalon, L. Perceived Age Discrimination: A Precipitator or a Consequence of Depressive Symptoms? J. Gerontol. Ser. B Psychol. Sci. Soc. Sci. 2018, 73, 860-869. [CrossRef] [PubMed]

340. Uddin, M.; Jansen, S.; Telzer, E.H. Adolescent depression linked to socioeconomic status? Molecular approaches for revealing premorbid risk factors. Bioessays 2017, 39, 1600194. [CrossRef]

341. Recto, P.; Champion, J.D. Psychosocial Risk Factors for Perinatal Depression among Female Adolescents: A Systematic Review. Issues Ment. Health Nurs. 2017, 38, 633-642. [CrossRef]

342. Ortiz, A.L.S.; Garcia, C.I.A.; Castillo, G.I.A. Determinants associated with chronic and incident depression in Mexican older adults. Gac. Med. De Mex. 2017, 153 (Suppl. 2), S102-S118.

343. Ojagbemi, A.; Akpa, O.; Elugbadebo, F.; Owolabi, M.; Ovbiagele, B. Depression after Stroke in Sub-Saharan Africa: A Systematic Review and Meta-Analysis. Behav. Neurol. 2017, 2017, 4160259. [CrossRef]

344. Neumann, E. Recollections of Emotional Abuse and Neglect in Childhood as Risk Factors for Depressive Disorders and the Need for Psychotherapy in Adult Life. J. Nerv. Ment. Dis. 2017, 205, 873-878. [CrossRef]

345. Nelson, J.; Klumparendt, A.; Doebler, P.; Ehring, T. Childhood maltreatment and characteristics of adult depression: Meta-analysis. Br. J. Psychiatry 2017, 210, 96-104. [CrossRef]

346. Najman, J.M.; Plotnikova, M.; Williams, G.M.; Alati, R.; Mamun, A.A.; Scott, J.; Clavarino, A.M.; Way, N. Maternal depression and family adversity: Linked pathways to offspring depression? J. Psychiatr. Res. 2017, 88, 97-104. [CrossRef]

347. Madsen, I.E.H.; Nyberg, S.T.; Hanson, L.L.M.; Ferrie, J.E.; Ahola, K.; Alfredsson, L.; Batty, G.; Bjorner, J.B.; Borritz, M.; Burr, H.; et al. Job strain as a risk factor for clinical depression: Systematic review and meta-analysis with additional individual participant data. Psychol. Med. 2017, 47, 1342-1356. [CrossRef] [PubMed]

348. Li, Y.; Long, Z.; Cao, D.; Cao, F. Maternal history of child maltreatment and maternal depression risk in the perinatal period: A longitudinal study. Child Abus. Negl. 2017, 63, 192-201. [CrossRef]

349. Leung, B.M.Y.; Apron the APrON Team; Letourneau, N.L.; Giesbrecht, G.F.; Ntanda, H.; Hart, M. Predictors of Postpartum Depression in Partnered Mothers and Fathers from a Longitudinal Cohort. Community Ment. Health J. 2016, 53, 420-431. [CrossRef] [PubMed]

350. Lee, C.-M.; Chang, C.-F.; Pan, M.-Y.; Hsu, T.-H.; Chen, M.-Y. Depression and Its Associated Factors Among Rural Diabetic Residents. J. Nurs. Res. 2017, 25,31-40. [CrossRef]

351. Joshi, S.; Mooney, S.J.; Rundle, A.G.; Quinn, J.W.; Beard, J.R.; Cerdá, M. Pathways from neighborhood poverty to depression among older adults. Health Place 2017, 43, 138-143. [CrossRef]

352. James, P.; Hart, J.E.; Banay, R.F.; Laden, F.; Signorello, L.B. Built Environment and Depression in Low-Income African Americans and Whites. Am. J. Prev. Med. 2016, 52, 74-84. [CrossRef] 
353. Bhandari, S.; Larson, M.E.; Kumar, N.; Stein, D. Association of Inflammatory Bowel Disease (IBD) with Depressive Symptoms in the United States Population and Independent Predictors of Depressive Symptoms in an IBD Population: A NHANES Study. Gut Liver 2017, 11, 512-519. [CrossRef]

354. Beshai, S.; Mishra, S.; Meadows, T.J.; Parmar, P.; Huang, V. Minding the gap: Subjective relative deprivation and depressive symptoms. Soc. Sci. Med. 2017, 173, 18-25. [CrossRef]

355. Amutah-Onukagha, N.N.; Doamekpor, L.A.; Gardner, M. An Examination of the Sociodemographic and Health Determinants of Major Depressive Disorder Among Black Women. J. Racial Ethn. Health Disparities 2016, 4, 1074-1082. [CrossRef]

356. Lee, S.Y.; Chou, K.L. Assessing the relative contribution of social exclusion, income-poverty, and financial strain on depressive symptoms among older people in Hong Kong. Aging Ment. Health 2019, 23, 1487-1495. [CrossRef]

357. Reding, K.; Schmidt, P.J.; Rubinow, D.R. Perimenopausal depression and early menopause: Cause or consequence? Menopause 2017, 24, 1333-1335. [CrossRef]

358. Houtepen, L.C.; Heron, J.; Suderman, M.J.; Fraser, A.; Chittleborough, C.R.; Howe, L.D. Associations of adverse childhood experiences with educational attainment and adolescent health and the role of family and socioeconomic factors: A prospective cohort study in the UK. PLoS Med. 2020, 17, e1003031. [CrossRef]

359. Zhou, A.Q.; Lee, H.Y.; Lee, R.M. Who has low health literacy and does it matter for depression? Findings from aggregated and disaggregated racial/ethnic groups. Cult. Divers. Ethn. Minor. Psychol. 2019, 25, 73-81. [CrossRef] [PubMed]

360. Tsai, W.; Lu, Q. Ambivalence over emotional expression and intrusive thoughts as moderators of the link between self-stigma and depressive symptoms among Chinese American breast cancer survivors. J. Behav. Med. 2018, 42, 452-460. [CrossRef]

361. Saul, A.; Taylor, B.; Simpson, J.S.; Ponsonby, A.-L.; Blizzard, L.; Dwyer, T.; McMorran, B.; Wood, B.; van der Mei, I.A. Polymorphism in the serotonin transporter gene polymorphisms (5-HTTLPR) modifies the association between significant life events and depression in people with multiple sclerosis. Mult. Scler. J. 2018, 25, 848-855. [CrossRef]

362. Mẹtel, D.; Arciszewska, A.; Daren, A.; Frydecka, D.; Cechnicki, A.; Gawęda, L. Resilience and cognitive biases mediate the relationship between early exposure to traumatic life events and depressive symptoms in young adults. J. Affect. Disord. 2019, 254, 26-33. [CrossRef]

363. Swartz, J.R.; Hariri, A.R.; Williamson, D.E. An epigenetic mechanism links socioeconomic status to changes in depression-related brain function in high-risk adolescents. Mol. Psychiatry 2017, 22, 209-214. [CrossRef]

364. Strasser, B.; Sperner-Unterweger, B.; Fuchs, D.; Gostner, J.M. Mechanisms of Inflammation-Associated Depression: Immune Influences on Tryptophan and Phenylalanine Metabolisms. Curr. Top. Behav. Neurosci. 2016, 31, 95-115. [CrossRef]

365. Shi, M.; Sun, H.; Xu, Y.; Wang, Z.; Cui, H.; Wang, C.; Liu, W.; An, G.; Hu, J. Methylation Status of the Serotonin Transporter Promoter CpG Island Is Associated with Major Depressive Disorder in Chinese Han Population: A Case-Control Study. J. Nerv. Ment. Dis. 2017, 205, 641-646. [CrossRef]

366. Santero, M.; Daray, F.M.; Prado, C.; Hernández-Vásquez, A.; Irazola, V. Association between religiosity and depression varies with age and sex among adults in South America: Evidence from the CESCAS I study. PLoS ONE 2019, 14, e0226622. [CrossRef]

367. Lac, A.; Austin, N.; Lemke, R.; Poojary, S.; Hunter, P. Association between religious practice and risk of depression in older people in the subacute setting. Australas. J. Ageing 2017, 36, E31-E34. [CrossRef]

368. Raudsepp, L. Brief report: Problematic social media use and sleep disturbances are longitudinally associated with depressive symptoms in adolescents. J. Adolesc. 2019, 76, 197-201. [CrossRef]

369. Virtanen, M.; Jokela, M.; Madsen, I.E.; Hanson, L.L.M.; Lallukka, T.; Nyberg, S.T.; Alfredsson, L.; Batty, G.D.; Bjorner, J.B.; Borritz, M.; et al. Long working hours and depressive symptoms: Systematic review and meta-analysis of published studies and unpublished individual participant data. Scand. J. Work. Environ. Health 2018, 44, 239-250. [CrossRef]

370. Dahlqvist, H.Z.; Gådin, K.G. Online sexual victimization in youth: Predictors and cross-sectional associations with depressive symptoms. Eur. J. Public Health 2018, 28, 1018-1023. [CrossRef]

371. Williams, N.; Jamal, S.; Guthrie, D.M. The relationship between caregiver burden and depressive symptoms in Ontario home care clients. Home Heal. Care Serv. Q. 2018, 37, 60-76. [CrossRef]

372. Didoné, L.S.; De Jesus, I.T.M.; Santos-Orlandi, A.A.; Pavarini, S.C.I.; Orlandi, F.D.S.; Costa-Guarisco, L.P.; Gratão, A.C.M.; Gramany-Say, K.; Cominetti, M.R.; Gomes, G.A.D.O.; et al. Factors associated with depressive symptoms in older adults in context of social vulnerability. Rev. Bras. Enferm. 2020, 73 (Suppl. S1), e20190107. [CrossRef]

373. Wen, S.; Xiao, H.; Yang, Y. The risk factors for depression in cancer patients undergoing chemotherapy: A systematic review. Support. Care Cancer 2018, 27, 57-67. [CrossRef]

374. Ruiz, M.; Malyutina, S.; Pajak, A.; Kozela, M.; Kubinova, R.; Bobak, M. Congruent relations between perceived neighbourhood social cohesion and depressive symptoms among older European adults: An East-West analysis. Soc. Sci. Med. 2019, $237,112454$. [CrossRef]

375. Hymas, R.; Girard, L.-C. Predicting postpartum depression among adolescent mothers: A systematic review of risk. J. Affect. Disord. 2018, 246, 873-885. [CrossRef] [PubMed]

376. Ren, P.; Qin, X.; Zhang, Y.; Zhang, R. Is Social Support a Cause or Consequence of Depression? A Longitudinal Study of Adolescents. Front. Psychol. 2018, 9, 1634. [CrossRef]

377. Cross-Denny, B. and M.A. Robinson, Using the Social Determinants of Health as a Framework to Examine and Address Predictors of Depression in Later Life. Ageing Int. 2017, 42, 393-412. [CrossRef] 
378. Almquist, Y.B.; Landstedt, E.; Hammarstrom, A. Associations between social support and depressive symptoms: Social causation or social selection-or both? Eur. J. Public Health 2017, 27, 84-89. [CrossRef]

379. Alhasanat, D.; Fry-McComish, J.; Yarandi, H.N. Risk for Postpartum Depression Among Immigrant Arabic Women in the United States: A Feasibility Study. J. Midwifery Women's Health 2017, 62, 470-476. [CrossRef]

380. Park, S.; Lee, Y.; Jun, J.Y. Trauma and Depression among North Korean Refugees: The Mediating Effect of Negative Cognition. Int. J. Env. Res. Public Health 2018, 15, 591. [CrossRef]

381. Petkus, A.J.; Beam, C.R.; Johnson, W.; Kaprio, J.; Korhonen, T.; McGue, M.; Neiderhiser, J.M.; Pedersen, N.L.; Reynolds, C.A.; Gatz, M.; et al. Gene-environment interplay in depressive symptoms: Moderation by age, sex, and physical illness. Psychol. Med. 2017, 47, 1836-1847. [CrossRef]

382. Ho, P.H.; Leung, W.C.-Y.; Leung, I.Y.; Chang, R.S. Factors associated with depression in people with epilepsy: A retrospective case-control analysis. Hong Kong Med. J. 2020. [CrossRef]

383. Poole, D.N.; Hedt-Gauthier, B.; Liao, S.; Raymond, N.A.; Bärnighausen, T. Major depressive disorder prevalence and risk factors among Syrian asylum seekers in Greece. BMC Public Health 2018, 18, 908. [CrossRef]

384. Bone, J.K.; Lewis, G.; Lewis, G. The role of gender inequalities in adolescent depression. Lancet Psychiatry 2020, 7, 471-472. [CrossRef]

385. Rantanen, A.T.; Korkeila, J.J.A.; Löyttyniemi, A.T.; Saxen, U.K.M.; Korhonen, P.E. Awareness of hypertension and depressive symptoms: A cross-sectional study in a primary care population. Scand J. Prim. Health Care 2018, 36, 323-328. [CrossRef] [PubMed]

386. Wellman, R.J.; Wilson, K.M.; O’Loughlin, E.K.; Dugas, E.N.; Montreuil, A.; O'Loughlin, J. Secondhand Smoke Exposure and Depressive Symptoms in Children: A Longitudinal Study. Nicotine Tob. Res. 2018, 22, 32-39. [CrossRef]

387. Zhang, C.; Fan, S.J.; Sun, A.B.; Liu, Z.Z.; Liu, L. Prenatal nicotine exposure induces depression-like behavior in adolescent female rats via modulating neurosteroid in the hippocampus. Mol. Med. Rep. 2019, 19, 4185-4194. [CrossRef] [PubMed]

388. Ye, X.; Huang, J.; Xia, L.; Xu, X.; Gong, X.; Xu, Y. Setting-Specific and Symptom-Specific Association between Secondhand Smoke Exposure and Depressive Symptoms. Int. J. Environ. Res. Public Health 2019, 16, 1249. [CrossRef] [PubMed]

389. Ranjit, A.; Buchwald, J.; Latvala, A.; Heikkilä, K.; Tuulio-Henriksson, A.; Rose, R.J.; Kaprio, J.; Korhonen, T. Predictive Association of Smoking with Depressive Symptoms: A Longitudinal Study of Adolescent Twins. Prev. Sci. 2019, 20, 1021-1030. [CrossRef]

390. Raffetti, E.; Donato, F.; Forsell, Y.; Galanti, M.R. Longitudinal association between tobacco use and the onset of depressive symptoms among Swedish adolescents: The Kupol cohort study. Eur. Child Adolesc. Psychiatry 2019, 28, 695-704. [CrossRef] [PubMed]

391. Pramod, B.R.; Mehdi, S.; Undela, K.; Kishor, M.; Rao, P.V.; Krishna, K.L. Lifestyle and substance use-an important cause for treatment-resistant depression and major depressive disorders. Drug Invent. Today 2019, 11, 284-290.

392. Huang, J.; Xu, B.; Guo, D.; Jiang, T.; Huang, W.; Liu, G.; Ye, X. Dose-Response Relationships between Second-Hand Smoke Exposure and Depressive Symptoms among Adolescents in Guangzhou, China. Int. J. Environ. Res. Public Health 2018, 15, 985. [CrossRef]

393. Wirth, M.D.; Shivappa, N.; Burch, J.B.; Hurley, T.G.; Hébert, J.R. The Dietary Inflammatory Index, shift work, and depression: Results from NHANES. Health Psychol. 2017, 36, 760-769. [CrossRef] [PubMed]

394. Li, Y.; Lv, M.-R.; Wei, Y.-J.; Sun, L.; Zhang, J.-X.; Zhang, H.-G.; Li, B. Dietary patterns and depression risk: A meta-analysis. Psychiatry Res. 2017, 253, 373-382. [CrossRef]

395. Cabello, M.; Miret, M.; Caballero, F.F.; Chatterji, S.; Naidoo, N.; Kowal, P.; D’Este, C.; Ayuso-Mateos, J.L. The role of unhealthy lifestyles in the incidence and persistence of depression: A longitudinal general population study in four emerging countries. Glob. Health 2017, 13, 18. [CrossRef]

396. Adjibade, M.; Andreeva, V.A.; Lemogne, C.; Touvier, M.; Shivappa, N.; Hebert, J.R.; Wirth, M.D.; Hercberg, P.G.; Galan, P.; Julia, C.; et al. The Inflammatory Potential of the Diet Is Associated with Depressive Symptoms in Different Subgroups of the General Population. J. Nutr. 2017, 147, 879-887. [CrossRef]

397. Sainz, M.T.; Nagy, G.; Mohedano, G.R.; Vélez, N.M.; García, S.C.; Cisneros, D.P.; Rey, G.N. The association between substance use and depressive symptomatology in nursing university students in Mexico. Nurse Educ. Pract. 2019, 36, 114-120. [CrossRef] [PubMed]

398. García-Esquinas, E.; Ortolá, R.; Galán, I.; Soler-Vila, H.; Laclaustra, M.; Rodríguez-Artalejo, F. Moderate alcohol drinking is not associated with risk of depression in older adults. Sci. Rep. 2018, 8, 11512. [CrossRef]

399. Wang, X.; Li, Y.; Fan, H. The associations between screen time-based sedentary behavior and depression: A systematic review and meta-analysis. BMC Public Health 2019, 19, 1524. [CrossRef]

400. Vancampfort, D.; Stubbs, B.; Firth, J.; Damme, T.V.; Koyanagi, A. Sedentary behavior and depressive symptoms among 67,077 adolescents aged 12-15 years from 30 low- and middle-income countries. Int. J. Behav. Nutr. Phys. Act. 2018, 15, 73. [CrossRef] [PubMed]

401. Hallgren, M.; Owen, N.; Stubbs, B.; Zeebari, Z.; Vancampfort, D.; Schuch, F.; Bellocco, R.; Dunstan, D.; Lagerros, Y.T. Passive and mentally-active sedentary behaviors and incident major depressive disorder: A 13-year cohort study. J. Affect. Disord. 2018, 241, 579-585. [CrossRef] [PubMed]

402. Zhang, M.; Li, Z.; Yang, S.; Sun, Y.; Jin, M.; Chen, X.; Yu, Q. The Association between Dietary Patterns and Depressive Symptoms in Chinese Adults. BioMed Res. Int. 2020, 2020, 8380151. [CrossRef] 
403. Yu, Y.; Xu, D.; Cheng, S.; Zhang, L.; Shi, Z.; Qin, J.; Zhang, Z.; Wang, H. Prenatal ethanol exposure enhances the susceptibility to depressive behavior of adult offspring rats fed a high-fat diet by affecting BDNF-associated pathway. Int. J. Mol. Med. 2019, 45, 365-374. [CrossRef] [PubMed]

404. Sahasrabudhe, N.; Lee, J.S.; Scott, T.M.; Punnett, L.; Tucker, K.L.; Palacios, N. Serum Vitamin D and Depressive Symptomatology among Boston-Area Puerto Ricans. J. Nutr. 2020, 150, 3231-3240. [CrossRef] [PubMed]

405. Nishida, S.; Araki, R.; Baba, A.; Asari, S.; Tachibana, S.; Nakajima, Y.; Iwakumo, A.; Yabe, T. Post-weaning folate deficiency induces a depression-like state via neuronal immaturity of the dentate gyrus in mice. J. Pharmacol. Sci. 2020, 143, 97-105. [CrossRef]

406. Mulugeta, A.; Lumsden, A.; Hyppönen, E. Relationship between Serum 25(OH)D and Depression: Causal Evidence from a Bi-Directional Mendelian Randomization Study. Nutrients 2020, 13, 109. [CrossRef]

407. Li, Y.; Zhang, C.; Li, S.; Zhang, D. Association between dietary protein intake and the risk of depressive symptoms in adults. Br. J. Nutr. 2020, 123, 1290-1301. [CrossRef] [PubMed]

408. Li, C.; Liu, Y.; Xu, P.; Fan, Q.; Gong, P.; Ding, C.; Sheng, L.; Zhang, X. Association between obstructive sleep apnea and risk of post-stroke depression: A hospital-based study in ischemic stroke patients. J. Stroke Cerebrovasc. Dis. 2020, 29, 104876. [CrossRef] [PubMed]

409. Klimova, B.; Novotny, M.; Valis, M. The Impact of Nutrition and Intestinal Microbiome on Elderly Depression-A Systematic Review. Nutrients 2020, 12, 710. [CrossRef]

410. Hayashi, A.; Oguchi, H.; Kozawa, Y.; Ban, Y.; Shinoda, J.; Suganuma, N. Factors associated with symptoms of depression among pregnant women with gestational diabetes mellitus in Japan. Drug Discov. Ther. 2020, 14, 232-238. [CrossRef]

411. Boulkrane, M.S.; Fedotova, J.; Kolodyaznaya, V.; Micale, V.; Drago, F.; Tol, A.J.M.V.D.; Baranenko, D. Vitamin D and Depression in Women: A Mini-review. Curr. Neuropharmacol. 2020, 18, 288-300. [CrossRef]

412. Wassef, A.; Nguyen, Q.D.; St-André, M. Anaemia and depletion of iron stores as risk factors for postpartum depression: A literature review. J. Psychosom. Obstet. Gynecol. 2017, 40, 19-28. [CrossRef] [PubMed]

413. Peppard, L.; Oh, K.M.; Gallo, S.; Milligan, R. Risk of depression in pregnant women with low-normal serum Vitamin B12. Res. Nurs. Health 2019, 42, 264-272. [CrossRef] [PubMed]

414. Libuda, L.; Laabs, B.-H.; Ludwig, C.; Bühlmeier, J.; Antel, J.; Hinney, A.; Naaresh, R.; Föcker, M.; Hebebrand, J.; König, I.R.; et al. Vitamin D and the Risk of Depression: A Causal Relationship? Findings from a Mendelian Randomization Study. Nutrients 2019, 11, 1085. [CrossRef]

415. Li, X.-D.; Cao, H.-J.; Xie, S.-Y.; Li, K.-C.; Tao, F.-B.; Yang, L.-S.; Zhang, J.-Q.; Bao, Y.-S. Adhering to a vegetarian diet may create a greater risk of depressive symptoms in the elderly male Chinese population. J. Affect. Disord. 2018, 243, 182-187. [CrossRef]

416. Kheirouri, S.; Alizadeh, M. Dietary Inflammatory Potential and the Risk of Incident Depression in Adults: A Systematic Review. Adv. Nutr. 2019, 10, 9-18. [CrossRef]

417. Hu, D.; Cheng, L.; Jiang, W. Sugar-sweetened beverages consumption and the risk of depression: A meta-analysis of observational studies. J. Affect. Disord. 2019, 25, 348-355. [CrossRef]

418. Grases, G.; Colom, M.A.; Sanchis, P.; Grases, F. Possible relation between consumption of different food groups and depression. BMC Psychol. 2019, 7, 14. [CrossRef]

419. Bolzetta, F.; Veronese, N.; Stubbs, B.; Noale, M.; Vaona, A.; Demurtas, J.; Celotto, S.; Cacco, C.; Cester, A.; Caruso, M.G.; et al. The Relationship between Dietary Vitamin K and Depressive Symptoms in Late Adulthood: A Cross-Sectional Analysis from a Large Cohort Study. Nutrients 2019, 11, 787. [CrossRef]

420. Boldarine, V.T.; Pedroso, A.; Neto, N.I.P.; Dornellas, A.P.S.; Nascimento, C.M.O.; Oyama, L.M.; Ribeiro, E.B. High-fat diet intake induces depressive-like behavior in ovariectomized rats. Sci. Rep. 2019, 9, 10551. [CrossRef]

421. Xu, H.; Li, S.; Song, X.; Li, Z.; Zhang, D. Exploration of the association between dietary fiber intake and depressive symptoms in adults. Nutrition 2018, 54, 48-53. [CrossRef]

422. Sainsbury, K.; Marques, M.M. The relationship between gluten free diet adherence and depressive symptoms in adults with coeliac disease: A systematic review with meta-analysis. Appetite 2018, 120, 578-588. [CrossRef] [PubMed]

423. Pittampalli, S.; Mekala, H.M.; Upadhyayula, S.; Lippman, S. Does Vitamin D Deficiency Cause Depression? Prim. Care Companion CNS Disord. 2018, 20, 18. [CrossRef]

424. Nathanson, R.; Hill, B.; Skouteris, H.; Bailey, C. Antenatal diet and postpartum depressive symptoms: A prospective study. Midwifery 2018, 62, 69-76. [CrossRef]

425. Miki, T.; Eguchi, M.; Akter, S.; Kochi, T.; Kuwahara, K.; Kashino, I.; Hu, H.; Kabe, I.; Kawakami, N.; Nanri, A.; et al. Longitudinal adherence to a dietary pattern and risk of depressive symptoms: The Furukawa Nutrition and Health Study. Nutrition 2018, 48, 48-54. [CrossRef]

426. Jorgensen, D.; White, G.E.; Sekikawa, A.; Gianaros, P. Higher dietary inflammation is associated with increased odds of depression independent of Framingham Risk Score in the National Health and Nutrition Examination Survey. Nutr. Res. 2018, 54, 23-32. [CrossRef]

427. LLi, Z.; Li, B.; Song, X.; Zhang, D. Dietary zinc and iron intake and risk of depression: A meta-analysis. Psychiatry Res. 2017, 251, 41-47. [CrossRef]

428. Firth, J.; Gangwisch, J.E.; Borsini, A.; Wootton, R.E.; Mayer, E.A. Food and mood: How do diet and nutrition affect mental wellbeing? Bmj 2020, 369, m2382. [CrossRef] 
429. Walker, W.H., 2nd; Borniger, J.C.; Gaudier-Diaz, M.M.; Melendez-Gernandez, O.H.; Pascoe, J.L.; DeVries, A.C.; Nelson, R.J. Acute exposure to low-level light at night is sufficient to induce neurological changes and depressive-like behavior. Mol. Psychiatry 2020, 25, 1080-1093. [CrossRef]

430. Quinn, D.M.; Puhl, R.M.; Reinka, M.A. Trying again (and again): Weight cycling and depressive symptoms in U.S. adults. PLoS ONE 2020, 15, e0239004. [CrossRef]

431. Manczak, E.M.; Miller, J.G.; Gotlib, I.H. Water contaminant levels interact with parenting environment to predict development of depressive symptoms in adolescents. Dev. Sci. 2020, 23, e12838. [CrossRef] [PubMed]

432. Lin, Y.-C.; Chang, Y.-H.; Yan, H.-T. Is trade a blessing or a curse? A panel data analysis of the determinants of depressive disorders. Int. J. Public Health 2020, 65, 1113-1121. [CrossRef]

433. Wang, R.; Liu, Y.; Xue, D.; Yao, Y.; Liu, P.; Helbich, M. Cross-sectional associations between long-term exposure to particulate matter and depression in China: The mediating effects of sunlight, physical activity, and neighborly reciprocity. J. Affect. Disord. 2019, 249, 8-14. [CrossRef] [PubMed]

434. Wang, R.; Xue, D.; Liu, Y.; Liu, P.; Chen, H. The Relationship between Air Pollution and Depression in China: Is Neighbourhood Social Capital Protective? Int. J. Environ. Res. Public Health 2018, 15, 1160. [CrossRef] [PubMed]

435. Pereira-Lima, K.; Gupta, R.R.; Guille, C.; Sen, S. Residency program factors associated with depressive symptoms in internal medicine interns: A prospective cohort study. Acad. Med. 2019, 94, 869-875. [CrossRef] [PubMed]

436. Werneck, A.O.; Oyeyemi, A.L.; Szwarcwald, C.L.; Vancampfort, D.; Silva, D. Associations between TV viewing and depressive symptoms among 60,202 Brazilian adults: The Brazilian national health survey. J. Affect. Disord. 2018, 236, 23-30. [CrossRef] [PubMed]

437. Hajek, A.; Brettschneider, C.; Bussche, H.V.D.; Lühmann, D.; Oey, A.; Wiese, B.; Weyerer, S.; Werle, J.; Fuchs, A.; Pentzek, M.; et al. Impact of falls on depressive symptoms among the oldest old: Results from the AgeQualiDe study. Int. J. Geriatr. Psychiatry 2018, 33, 1383-1388. [CrossRef]

438. Meng, G.; Ma, X.; Li, L.; Tan, Y.; Liu, X.; Liu, X.; Zhao, Y. Predictors of early-onset post-ischemic stroke depression: A cross-sectional study. BMC Neurol. 2017, 17, 199. [CrossRef]

439. Weissman, M.M.; Talati, A.; Hao, X.; Posner, J. Risks for major depression: Searching for stable traits. Biol. Psychiatry 2018, 83, 7-8. [CrossRef] [PubMed]

440. Milenkovic, V.M.; Stanton, E.H.; Nothdurfter, C.; Rupprecht, R.; Wetzel, C.H. The role of chemokines in the pathophysiology of major depressive disorder. Int. J. Mol. Sci. 2019, 20, 2283. [CrossRef] [PubMed]

441. Jia, C.; Brown, R.W.; Malone, H.M.; Burgess, K.C.; Gill, W.D.; Keasey, M.P.; Hagg, T. Ciliary neurotrophic factor is a key sex-specific regulator of depressive-like behavior in mice. Psychoneuroendocrinology 2018, 100, 96-105. [CrossRef] [PubMed]

442. Jacobson, L. Glucocorticoid receptor deletion from locus coeruleus norepinephrine neurons promotes depression-like social withdrawal in female but not male mice. Brain Res. 2018, 1710, 82-91. [CrossRef]

443. Innes, S.; Pariante, C.M.; Borsini, A. Microglial-driven changes in synaptic plasticity: A possible role in major depressive disorder. Psychoneuroendocrinology 2018, 102, 236-247. [CrossRef]

444. Hu, Y.; Hong, X.Y.; Yang, X.F.; Ma, R.H.; Wang, X.; Zhang, J.F.; Feng, Q.; Li, X.G.; Sun, D.S.; Li, X.; et al. Inflammation-dependent ISG15 upregulation mediates MIA-induced dendrite damages and depression by disrupting NEDD4/Rap2A signaling. Biochim. Biophys. Acta Mol. Basis Dis. 2019, 1865, 1477-1489. [CrossRef] [PubMed]

445. Chen, F.; Yu, X.; Meng, G.; Mei, Z.; Du, Y.; Sun, H.; Reed, M.N.; Kong, L.; Suppiramaniam, V.; Hong, H.; et al. Hippocampal genetic knockdown of PPAR $\delta$ causes depression-like behaviors and neurogenesis suppression. Int. J. Neuropsychopharmacol. 2019, 22, 372-382. [CrossRef]

446. Zhang, Z.; Zhang, P.; Qi, G.-J.; Jiao, F.-J.; Wang, Q.-Z.; Yan, J.-G.; He, F.; Zhang, Q.; Lv, Z.-X.; Peng, X.; et al. CDK5-mediated phosphorylation of Sirt2 contributes to depressive-like behavior induced by social defeat stress. Biochim. Biophys. Acta Mol. Basis Dis. 2018, 1864, 533-541. [CrossRef] [PubMed]

447. Wigner, P.; Czarny, P.; Galecki, P.; Su, K.-P.; Sliwinski, T. The molecular aspects of oxidative \& nitrosative stress and the tryptophan catabolites pathway (TRYCATs) as potential causes of depression. Psychiatry Res. 2018, 262, 566-574. [CrossRef] [PubMed]

448. Perin, S.; Harrington, K.D.; Lim, Y.Y.; Ellis, K.; Ames, D.; Pietrzak, R.H.; Schembri, A.; Rainey-Smith, S.; Salvado, O.; Laws, S.M.; et al. Amyloid burden and incident depressive symptoms in preclinical Alzheimer's disease. J. Affect. Disord. 2018, 229, 269-274. [CrossRef]

449. Zhang, J.; Chen, L.; Ma, J.; Qiao, Z.; Zhao, M.; Qi, D.; Zhao, Y.; Ban, B.; Zhu, X.; He, J.; et al. Interaction of estrogen receptor $\beta$ and negative life events in susceptibility to major depressive disorder in a Chinese Han female population. J. Affect. Disord. 2016, 208, 628-633. [CrossRef]

450. Yohn, C.N.; Gergues, M.M.; Samuels, B.A. The role of 5-HT receptors in depression. Mol. Brain 2017, 10, 1-12. [CrossRef]

451. Stange, J.P.; Hamilton, J.L.; Fresco, D.M.; Alloy, L.B. Perseverate or decenter? Differential effects of metacognition on the relationship between parasympathetic inflexibility and symptoms of depression in a multi-wave study. Behav. Res. Ther. 2017, 97, 123-133. [CrossRef]

452. Rudzki, L.; Pawlak, D.; Pawlak, K.; Waszkiewicz, N.; Małus, A.; Konarzewska, B.; Gałęcka, M.; Bartnicka, A.; Ostrowska, L.; Szulc, A. Immune suppression of IgG response against dairy proteins in major depression. BMC Psychiatry 2017, 17, 268. [CrossRef] 
453. Pereira, J.C., Jr.; Hallinan, M.P.; Alves, R.C. Secondary to excessive melatonin synthesis, the consumption of tryptophan from outside the blood-brain barrier and melatonin over-signaling in the pars tuberalis may be central to the pathophysiology of winter depression. Med. Hypotheses 2017, 98, 69-75. [CrossRef]

454. Schnittker, J. In-utero determinants of adult depression: Evidence from the 1918 flu pandemic. Biodemography Soc. Biol. 2019, 65, 227-244. [CrossRef]

455. Hunt, C.; e Cordeiro, T.M.; Suchting, R.; de Dios, C.; Leal, V.A.C.; Soares, J.C.; Dantzer, R.; Teixeira, A.L.; Selvaraj, S. Effect of immune activation on the kynurenine pathway and depression symptoms-A systematic review and meta-analysis. Neurosci. Biobehav. Rev. 2020, 118, 514-523. [CrossRef] [PubMed]

456. An, H.; Han, J.W.; Jeong, H.-G.; Kim, T.H.; Lee, J.J.; Lee, S.B.; Park, J.H.; Kim, K.W. Parasympathetic predominance is a risk factor for future depression: A prospective cohort study. J. Affect. Disord. 2019, 260, 232-237. [CrossRef] [PubMed]

457. Ihongbe, T.O.; Masho, S.W. Do successive preterm births increase the risk of postpartum depressive symptoms? J. Pregnancy 2017, 2017, 4148136. [CrossRef]

458. Teshigawara, T.; Mouri, A.; Kubo, H.; Nakamura, Y.; Shiino, T.; Okada, T.; Morikawa, M.; Nabeshima, T.; Ozaki, N.; Yamamoto, Y.; et al. Changes in tryptophan metabolism during pregnancy and postpartum periods: Potential involvement in postpartum depressive symptoms. J. Affect. Disord. 2019, 255, 168-176. [CrossRef]

459. Smeeth, D.; Dima, D.; Jones, L.; Jones, I.; Craddock, N.; Owen, M.J.; Rietschel, M.; Maier, W.; Korszun, A.; Rice, J.P.; et al. Polygenic risk for circulating reproductive hormone levels and their influence on hippocampal volume and depression susceptibility. Psychoneuroendocrinology 2019, 106, 284-292. [CrossRef]

460. Illes, P.; Rubini, P.; Yin, H.; Tang, Y. Impaired ATP release from brain astrocytes may be a cause of major depression. Neurosci. Bull. 2020, 36, 1281-1284. [CrossRef] [PubMed]

461. Enko, D.; Wagner, H.; Kriegshäuser, G.; Brandmayr, W.; Halwachs-Baumann, G.; Schnedl, W.J.; Zelzer, S.; Mangge, H.; Meinitzer, A. Assessment of tryptophan metabolism and signs of depression in individuals with carbohydrate malabsorption. Psychiatry Res. 2018, 262, 595-599. [CrossRef]

462. Çelikel, O.O.; Bulut, S. Evaluation of the relationship between sexual functions and depressive symptoms among pregnant patients during the second trimester. Arch. Gynecol. Obstet. 2019, 300, 1813-1819. [CrossRef]

463. Duan, Z.; Shan, W.; Du, H.; Xu, M.; Feng, J.; Qiu, C.; Ling, Y. Association between serum retinoic acid levels and risk of post-stroke depression in patients with ischemic stroke. Asian J. Psychiatry 2019, 46, 87-91. [CrossRef]

464. Haleem, D.J. Glucocorticoids in the physiological and transcriptional regulation of 5-ht1a receptor and the pathogenesis of depression. Neuroscientist 2020. [CrossRef]

465. Tao, R.; Fu, Z.; Xiao, L. Chronic food antigen-specific igg-mediated hypersensitivity reaction as a risk factor for adolescent depressive disorder. Genomics Proteomics Bioinf. 2019, 17, 183-189. [CrossRef]

466. Chen, H.; Luan, X.; Zhao, K.; Qiu, H.; Liu, Y.; Tu, X.; Tang, W.; He, J. The association between neutrophil-to-lymphocyte ratio and post-stroke depression. Clin. Chim. Acta 2018, 486, 298-302. [CrossRef]

467. Xu, H.; Ding, Y.; Ma, Y.; Xin, X.; Zhang, D. Cesarean section and risk of postpartum depression: A meta-analysis. J. Psychosom. Res. 2017, 97, 118-126. [CrossRef]

468. Nam, J.Y.; Choi, Y.; Kim, J.; Cho, K.H.; Park, E.-C. The synergistic effect of breastfeeding discontinuation and cesarean section delivery on postpartum depression: A nationwide population-based cohort study in Korea. J. Affect. Disord. 2017, 218, 53-58 [CrossRef]

469. Ashokan, A.; Hegde, A.; Balasingham, A.; Mitra, R. Housing environment influences stress-related hippocampal substrates and depression-like behavior. Brain Res. 2018, 1683, 78-85. [CrossRef]

470. Liu, S.; Yan, Y.; Gao, X.; Xiang, S.; Sha, T.; Zeng, G.; He, Q. Risk factors for postpartum depression among Chinese women: Path model analysis. BMC Pregnancy Childbirth 2017, 17, 133. [CrossRef]

471. Gorlova, A.V.; Pavlov, D.A.; Ushakova, V.M.; Zubkov, E.A.; Morozova, A.Y.; Inozemtsev, A.N.; Chekhonin, V.P. Dynamics of the development of depressive-like state in rats stressed by chronic exposure of ultrasound of variable frequency. Bull. Exp. Biol. Med. 2017, 163, 296-298. [CrossRef]

472. Angerer, P.; Schmook, R.; Elfantel, I.; Li, J. Night Work and the Risk of Depression. Dtsch. Aerzteblatt Online 2017, $114,404-411$. [CrossRef]

473. García, F.E.; Cova, F.; Páez, D.; Miranda, F. Brooding as moderator of depressive symptoms after a work accident: A longitudinal study. Scand. J. Psychol. 2018, 59, 236-242. [CrossRef]

474. Cissé, Y.M.; Russart, K.L.; Nelson, R.J. Depressive-like behavior is elevated among offspring of parents exposed to dim light at night prior to mating. Psychoneuroendocrinology 2017, 83, 182-186. [CrossRef]

475. Torres-Berrío, A.; Issler, O.; Parise, E.M.; Nestler, E.J. Unraveling the epigenetic landscape of depression: Focus on early life stress. Dialogues Clin. Neurosci. 2019, 21, 341-357.

476. Zhao, M.; Chen, L.; Yang, J.; Han, D.; Fang, D.; Qiu, X.; Yang, X.; Qiao, Z.; Ma, J.; Wang, L.; et al. BDNF Val66Met polymorphism, life stress and depression: A meta-analysis of gene-environment interaction. J. Affect. Disord. 2017, 227, 226-235. [CrossRef]

477. Tozzi, L.; Farrell, C.; Booij, L.; Doolin, K.; Nemoda, Z.; Szyf, M.; Pomares, F.B.; Chiarella, J.; O’Keane, V.; Frodl, T. Epigenetic Changes of FKBP5 as a Link Connecting Genetic and Environmental Risk Factors with Structural and Functional Brain Changes in Major Depression. Neuropsychopharmacology 2017, 43, 1138-1145. [CrossRef] 
478. Naoi, M.; Maruyama, W.; Shamoto-Nagai, M. Type A monoamine oxidase and serotonin are coordinately involved in depressive disorders: From neurotransmitter imbalance to impaired neurogenesis. J. Neural Transm. 2017, 125, 53-66. [CrossRef]

479. Bleys, D.; Luyten, P.; Soenens, B.; Claes, S. Gene-environment interactions between stress and 5-HTTLPR in depression: A meta-analytic update. J. Affect. Disord. 2018, 226, 339-345. [CrossRef] [PubMed]

480. Van Assche, E.; Moons, T.; Cinar, O.; Viechtbauer, W.; Oldehinkel, A.J.; Leeuwen, K.V.; Verschueren, K.; Colpin, H.; Lambrechts, D.; Noortgate, W.V.D.; et al. Gene-based interaction analysis shows GABAergic genes interacting with parenting in adolescent depressive symptoms. J. Child Psychol. Psychiatry 2017, 58, 1301-1309. [CrossRef]

481. Han, D.; Qiao, Z.; Chen, L.; Qiu, X.; Fang, D.; Yang, X.; Ma, J.; Chen, M.; Yang, J.; Wang, L.; et al. Interactions between the vascular endothelial growth factor gene polymorphism and life events in susceptibility to major depressive disorder in a Chinese population. J. Affect. Disord. 2017, 217, 295-298. [CrossRef]

482. Solar, O.; Irwin, A. A Conceptual Framework for Action on the Social Determinants of Health, Determinants of Health Discussion Paper 2 (Policy and Practice); The World Health Organization: Geneva, Switzerland, 2010.

483. Compton, M.T.; Shim, R.S. The Social Determinants of Mental Health; American Psychiatric Publishing: Washington, DC, USA, 2015.

484. Cohen, S.; Janicki-Deverts, D.; Doyle, W.J.; Miller, G.E.; Frank, E.; Rabin, B.S.; Turner, R.B. Chronic stress, glucocorticoid receptor resistance, inflammation, and disease risk. Proc. Natl. Acad. Sci. USA 2012, 109, 5995-5999. [CrossRef]

485. Burke, T.A.; Ammerman, B.A.; Hamilton, J.L.; Stange, J.P.; Piccirillo, M. Nonsuicidal self-injury scar concealment from the self and others. J. Psychiatr. Res. 2020, 130, 313-320. [CrossRef] 